\title{
İç Batı Anadolu Neolitik-Kalkolitiğine Dair Yeni Bulgular: Düzkışla Höyük, Uşak
}

\section{New Insights Regarding the Neolithic-Chalcolithic of the Inner- West Anatolia: Düzkışla Höyük, Uşak}

\author{
Mehmet Ali Y1lmaz ${ }^{1}$ (D)
}

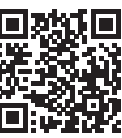

1Sorumlu yazar/Corresponding author: Mehmet Ali Yılmaz (Dr. Öğr. Üyesi), Uşak Üniversitesi, Fen Edebiyat Fakültesi, Arkeoloji Bölümü, Ankara, Türkiye E-posta: mehmetaliylmz@gmail.com ORCID ID: 0000-0002-3082-9691

Başvuru/Submitted: 29.06 .2020 Kabul/Accepted: 04.09 .2020

Öz

Neolitik yaşam biçiminin dağılımı ve yayılımını anlamak son yüzyılın önemli araştırma konularından birisidir. Araştırmalar, başlangıçta 'çekirdek' bölgenin dışında tutulan Anadolu'nun, yerleşik yaşama ve yiyecek üretimciliğine geçiş süreçlerinde kilit rollerden birini oynadığını göstermiştir. Bu makalede ele alınan Düzkışla Höyüğü 2019 yılında Uşak Protohistorik Dönem Yüzey Araştırmaları Projesi (UPDAP) çalışmalarında tespit edilmiş olup İç Batı Anadolu Neolitik Çağıyla ilgili çeşitli bilgiler vermektedir. Alandan elde edilen zengin buluntu topluluğu, bölgelerarası karşılaştırmalar yapmaya ve prehistorik dönemlerde bölgenin çevre kültürlerle olan ilişkileriyle ilgili çıkarımlara ulaşımasına imkân tanımaktadır. Kıyı Ege, Göller Yöresi, İç Anadolu ve Kuzeybatı Anadolu'nun tam kesişme noktasında yer alan Uşak, Neolitik Dönemde Anadolu'nun farklı bölgeleri arasındaki iletişim ve etkileşim ağlarının oluşmasında ve gelişmesinde önemli bir rol oynamış olmalıdır. Kapsamlı değerlendirilen Geç Neolitik- Erken Kalkolitik Çağ Düzkışla Höyük buluntuları, erken çiftçi yaşam biçiminin yerel karakterini ve bölgeler arası kültürel ilişkilerin boyutunu göstermesi açısından önemlidir.

Anahtar Kelimeler: Neolitik, Kalkolitik, Yüzey araştırması, İç Batı Anadolu, Uşak

\section{ABSTRACT}

Understanding the distribution and expansion of the Neolithic way of life was one of the important research topics of the last century. Studies demonstrated that Anatolia, which was originally excluded from the 'core' region, played a key role in the transition from hunter-gatherers to settled life and food production. This article focuses on Düzkışla Höyük, which was discovered during the Uşak Protohistoric Period Survey Project (UPDAP) in 2019 and which provides various information about the Neolithic Age of Western Anatolia. A rich collection of small finds from the site allows for cross-regional comparisons and conclusions about the region's relationship with its surrounding cultures during prehistoric times. Being on the crossroads of the Aegean coast, the Lakes Region, and Central and Northwest Anatolia, Uşak must have played an important role in the formation and development of communication and interaction networks in the Neolithic Period. The finds of the Late Neolithic-Early Chalcolithic Age from Düzkışla Höyük, which have been evaluated extensively, point to the local character of the way of life of early farmers on the one hand and the extent of cultural relations between regions on the other.

Keywords: Neolithic, Chalcolithic, Survey, Inner-West Anatolia, Uşak 


\section{EXTENDED ABSTRACT}

At the end of the Paleolithic Age, several changes in the lifestyle of hunter-gatherer communities led to technological, economic, social, and ideological developments which were previously subsumed under the term 'Neolithic Revolution.' Even though the term 'Neolithic' changes from researcher to researcher and region to region, in general, the discussions of the last one hundred years persist in focusing on the transition from a huntergatherer life to food production and a settled life. This is especially true for the questions of where, when, why, and how this transition occurred. At the outset of Neolithic research, it was assumed that the people of Anatolia were not involved in the development of settled life and food production. These activities seemed to have appeared exclusively within the socalled "Fertile Crescent." In contrast to this preconception, an increasing number of studies in the last 25 years have proven that Anatolia played a pivotal role in the transition to settled life and food production. In comparison to Southwestern Asia and Southeastern Europe, the low number of prehistoric excavations in Anatolia must be kept in mind. In this respect, research has accelerated over the last 50 years in Inner Anatolia, the Lakes Region, and Western and Northwestern Anatolia, which has expanded our knowledge considerably.

Within the "Uşak Protohistorical Survey Project" (Uşak Protohistorik Dönem Yüzey Araştırmaları Projesi/UPDAP), which began in 2017, a considerable number of pre- and proto-historical settlements were discovered for the first time. One of these settlements - and the focus of this paper-is named Düzkışla Höyük. The site of Düzkışla Höyük was founded on a slope which consists of conglomerate forms. Other recently discovered Neolithic sites such as Altıntaş, Ada Höyük, and Mercimekli Tepe are seen to usually be founded on ridges, valleys, or on the tops of hills. In contrast, research in the plains of Banaz and Uşak have revealed no signs of Neolithic or Chalcolithic settlements. An explanation for this could be that farming communities preferred settlements on ridges, valleys, and hills in close connection to raw materials or other resources. Clay deposits and a variety of multiple types of stones - for the production of pottery and stone tools - were proven to exist in this area after macroscopic investigations and analyses of raw material sources were conducted.

Most of the small finds collected at Düzkışla Höyük belong to the material culture of the Neolithic and Early Chalcolithic settlements of Western Anatolia. Painted sherds and sherds with a simple burnished pattern form the largest group. Terracotta figurines comprise another group of characteristic finds. One of the two figurines found on the surface of Düzkışla Höyük is a type of steatopygous woman with inserted heads; the other is a conic figurine of unknown sex. Two sling stones complete the group of terracotta finds. The category of stone finds is comprised of grinding stones made of limestone, basalt, andesite, and serpentine; bowls made of marble; as well as many examples of obsidian and flint blades. 
Concerning the distribution of the Neolithic lifestyle, Düzkışla Höyük was located on an important route. Recent research results have shown that the Neolithic and Chalcolithic cultures of the Lakes Region reached the territory of Uşak by two different routes. One route passed the northeast side of Burdur Lake and continued via Dinar, Sandıklı, and Hocalar to Uşak. This route is confirmed by the finds collected on the surface of the settlements at Üçin, Bektaş Üyük Tepe, Devlethan, and Asarın Tepe. The other route possibly passed the Çivril Plain and continued north where the key site of Ekşi Höyük is located. Its excavator maintains that the small finds from Ekşi Höyük reflect the characteristics of the Lakes Region. It is misleading to think that the inner part of Western Anatolia was culturally influenced from only a single direction. The Neolithic and early Chalcolithic cultures of Western Anatolia also influenced the inner part of Western Anatolia. The excavation finds from Ekşi Höyük and the survey finds from Düzkışla Höyük support this assertion.

Throughout previous studies, attempts were made to define the period of occupation of Düzkışla Höyük, from its beginning to its end. With great probability, the pottery and small finds can be dated between 6300/6200-5800/5700 BC. These dates suggest that Düzkışla Höyük was the first site inhabited in the surrounding area of Uşak during the Late Neolithic to the Early Chalcolithic Period. This site also shows the local characteristics of the way of life of early farmers as well as cultural relationships with neighboring regions. 


\section{Giriş}

Paleolitik Çağ sonunda avcı-toplayıcı grupların yaşam tarzında izlenen bazı değişimlerin beraberinde getirdiği teknolojik, ekonomik, sosyal ve ideolojik gelişmeler kimi zaman bir 'devrim' olarak da nitelendirilen Neolitik Çağ içinde izlenir. Bir kavram olarak "Neolitik" araştırmacıdan araştırmacıya veya bölgeden bölgeye değişiklik gösterebilse de genel olarak, yerleşik yaşam ve yiyecek üretimciliğine geçişin nerede, ne zaman, nasıl ve neden başladığı ile ilgili tartışmalar neredeyse yüzyıldır süregelmektedir (Sherratt, 2004; Çilingiroğlu, 2005, s. 1-2). Anadolu Neolitiği, Çayönü ve Çatalhöyük gibi kazılarla birlikte akademik tartışmaların konusu olurken, Batı Anadolu'da Neolitik Çağ’ın başlangıcı ve gelişimi 1990'ların ortalarına kadar bilinmezliğini korumaktaydı. Batı Anadolu Neolitik araştırmaları özellikle bu dönemden sonra artışa geçmiş olsa da genellikle İzmir ve çevresinde yürütülen kazı çalışmaları Kıyı Ege üzerindeki bilgilerimizin artmasını sağlamış; ancak İç Batı Anadolu bu konuda geri planda kalmaya devam etmiştir. Bu nedenle, İç Batı Anadolu'da çoğunluğu sistematik yüzey araştırmalarıyla elde edilen Neolitik Çağ'a ilişkin veriler önemli bir araştırma boşluğunu kısmen de olsa doldurma şansına sahiptir. Bu makalede ele alınan Düzkışla Höyüğü 2019 yılında Uşak Protohistorik Dönem Yüzey Araştırmaları Projesi (UPDAP) çalışmalarında tespit edilmiş olup İç Batı Anadolu Neolitik Çağıyla ilgili çeşitli bilgiler vermektedir.

Bu yazıda, ilk olarak Anadolu ve Batı Anadolu'daki Neolitik araştırma tarihçesine kısaca değinildikten sonra Düzkışla Höyüğü'nün yer aldığı coğrafya, yerleşimin konumu ve yerleşim şablonu tanıtılmakta; sonrasında materyal kültür tanımı ve göreli tarihlendirmesi yapılmaktadır. Alandan elde edilen zengin buluntu topluluğu, bölgelerarası karşılaştırmalar yapmaya ve prehistorik dönemlerde bölgenin çevre kültürlerle olan ilişkileriyle ilgili çıkarımlara ulaşılmasına imkân tanımaktadır. Kıyı Ege, GöllerYöresi, İç Anadolu ve Kuzeybatı Anadolu'nun tam kesişme noktasında yer alan Uşak, Neolitik Dönemde Anadolu'nun farklı bölgeleri arasındaki iletişim ve etkileşim ağlarının oluşmasında ve gelişmesinde önemli bir rol oynamış olmalıdır.

\section{Anadolu Neolitik Araştırmaları}

Neolitik araştırmaların başlangıcında, Anadolu toplumlarının yerleşik yaşama ve yiyecek üretimciliğine geçişte sahip olduğu önem görmezden gelinmiş; bu süreçlerin "Verimli Hilal" olarak adlandırılan bir "çekirdek” bölgeyle sınırlı kaldığı varsayılmıştır (Özdoğan, 2011, s. 419). Söz konusu önkabullerin aksine, son çeyrek yüzyıl içinde yapılan çalışmaların artışına koşut olarak Anadolu'nun yerleşik yaşama ve yiyecek üretimciliğine geçiş süreçlerinde en kilit rollerden birini oynadığı kesinleşmiştir.

Güneybatı Asya ve Güneydoğu Avrupa’ya kıyasla Anadolu'daki Prehistorik dönem kazı çalışmalarının sayıca eksikliği halen dikkat çekicidir. Bu eksiklikten ötürü, Çayönü, Çatalhöyük 
ve Hacılar gibi yerleşimlerin kazılması bile Anadolu'yu ikincil önemdeki bir Neolitik bölge olmaktan ileri taşıyamamıştı (Özdoğan, 2010, s. 884). İlk olarak I. Todd tarafından araştırılan Aşıklı Höyük’te, Çatalhöyük'ten yaklaşık 1000 yıl önceye giden verilerin tespit edilmesi dönemin önemli keşiflerindendir. 1993 yılında I. Hodder tarafından yeniden başlatılan araştırmalarla Çatalhöyük'ün ve D. Baird tarafından yürütülen kazılarla Boncuklu'nun Konya Ovası'nın tarihi MÖ 9. binyıla kadar giden Neolitik Dönem yerleşmeleri olduğu; U. Esin ve M. Özbaşaran'ın çalışmalarıyla da tarihi MÖ 9. binyıla giden tabakalara sahip Aşıklı'nın Kapadokya Bölgesi'nin önde gelen Neolitik temsilcileri olduğu günümüzde kesinleşmiştir (Özbaşaran, 2013; Baird, 2012; Hodder, 2012). Bu anahtar yerleşmelere ek olarak Can Hasan III veya Musular gibi Çanak Çömleksiz Neolitik Dönem yerleşimleriyle beraber Neolitiğin oluşum bölgesi Orta Anadolu'ya kadar genişler (Özbaşaran ve Cutting 2007).

Neolitiğin batıya uzanımında önemli bir anahtar bölge olan Göller Yöresi’nde J. Mellaart tarafından gerçekleştirilen araştırmalar, Neolitik Çağ kronolojisine yönelik ilk bilgileri üretmiştir. Önce bölgede yürütülen yüzey araştırmaları (Mellaart, 1954; Mellaart, 1961) ve ardından Hacılar'da gerçekleşen kazılar (Mellaart, 1970), Anadolu Neolitik ve Erken Kalkolitik Çă̆ kronolojilerinin temelini atar. R. Duru tarafından 1970'lerin sonundan itibaren Hacılar, Kuruçay, Bademağacı ve Höyücek’te gerçekleştirilen kazılar, Göller Yöresi Neolitik ve Kalkolitik Çağ kronolojisini revize etme şansı sunmuştur (Duru, 2007, s. 331-360; Duru, 2012). Diğer yandan, Yukarı Menderes Havzası'nda ilk olarak E. Abay (Abay, 2011, s. 20-21), sonrasında ise F. Dedeoğlu tarafından devam ettirilen yüzey araştırmaları (Dedeoğlu, 2014, s. 33-56) ile Ekşi Höyük’te başlayan kazılar (Dedeoğlu vd., 2018, s. 553-568), bu bölgedeki Neolitik ve Kalkolitik Çağ kültürlerinin ilk defa tanımlanmasına olanak sağlamıştır.

Elbette ki Anadolu'nun Neolitikleşme süreci binlerce yıllık süreci kapsayan bir zaman diliminde gerçekleşmiştir. Batı Anadolu Neolitik Çağı ise 1995 yılında başlayan Ulucak kazılarıyla ilk defa bir ivme kazanmıştır. Ulucak ve Çukuriçi’ndeki son arkeolojik araştırmalar doğrultusunda Batı Anadolu'nun Neolitikleşme sürecini MÖ 7. binyılın ilk yarısına kadar geri çekmek mümkün olmaktadır (Çilingiroğlu, 2012, s. 15-18; Horejs, 2017, s. 18). Bu kapsamda batıya yayılım sürecinin başlangıcının olasılıkla MÖ 7. binyıldan hemen önce olduğu düşünülmektedir. Neolitikleşme süreci her ne kadar bu tarihler olarak düşünülse de MÖ 8. binyılda bölgede dolaşan öncü grupların varlığından söz edilmektedir (Horejs vd., 2015, s. 295; Çilingiroğlu, 2017, s. 34-35). Bölgedeki diğer çalışmalarla birlikte Batı Anadolu Neolitiği ile ilgili Ulucak (Çilingiroğlu, Çevik ve Çilingiroğlu 2012, s. 139-175), Yeşilova (Derin, 2012, s. 177-195), Ege Gübre (Sağlamtimur, 2012, s. 197-225) ve Çukuriçi Höyük (Horejs, 2012, s. 117-131; Horejs, 2017) gibi yerleşimler, Orta Anadolu ve Kita Yunanistan arasındaki araştırma boşluğunu kapatan yeni veriler üretmiştir.

MÖ 7. binyılın ilk yarısında Neolitik gruplarca yerleşilen bölgelerden biri de Kuzeybatı Anadolu'dur. $\mathrm{Bu}$ yayılımın olasılıkla Orta Anadolu'nun batı bölümü üzerinden kuzeye, 
Sakarya Vadisi'ni takip ederek Marmara Bölgesi’ne uzandığı görülmektedir (Özdoğan, 2010, 885). Buraya yerleşen erken çiftçi gruplar Barcın, Aktopraklık, Menteşe ve Ilıpınar gibi yerleşmeleri kurmuşlardır. Özdoğan'a (2018, s. 9, 21) göre, Marmara Bölgesi'ne ilk gelen çiftçi gruplar ilk olarak Ağaçlı Kültürü’yle kaynaştıktan sonra avcı, balıkçı ve çiftçi özellikleri taşıyan 'Fikirtepe Kültürü'nü oluşturmuşlardır. Söz konusu rota üzerinde yer alan Kütahya ve Eskişehir'de Keçiçayırı (Sarı ve Akyol 2019) ve Demirci Höyük (Seeher, 1987) gibi önemli merkezlerin yanında yüzey araştırmalarıyla tespit edilmiş Akmakça, Fındık Kayabaşı (Efe, 1995) ve Mantarlık ve gibi Neolitik yerleşim yerlerinden elde edilen veriler oldukça önemlidir. Bilecik'te yer alan Bahçelievler yerleşmesindeki kurtarma kazıları sayesinde ilk defa bu yörede de MÖ 7. binyılın ilk yarısına tarihlenen yerleşmeler olduğu anlaşılmış oldu (Efe, Türkteki, Sarı ve Fidan 2015, s. 496-497; Fidan ve Küçükaydın 2019-2020, s. 96).

\section{Prehistorik Dönemde Uşak}

İç Batı Anadolu, Neolitik yaşam biçiminin Orta Anadolu'dan Batı Anadolu'ya yayılımının araştırılmasında şüphesiz kilit bir coğrafi bölgedir. Bu önemine rağmen, çok yakın zamana kadar bölgede Neolitik araştırmalar gerçekleşmemiştir. Uşak ise İç Batı Anadolu'nun belki de en az araştırma gerçekleştirilen bölümüdür. Bu bölümün Paleolitiği ile ilgili ilk keşif, 2016 yılında keşfedilen Banaz/Sürmecik buluntu yeridir. Bir maden sahası içinde çok sayıda yontmataş aletler ve bunlarla ilişkili hayvan fosillerine tesadüfen rastlanması sonucunda alanda kurtarma kazıları gerçekleşmiş; kazılar sonucunda zengin bir buluntu topluluğuna sahip Orta Paleolitik Çağ'a ait bir açık hava buluntu yerinin varlığı ortaya konmuştur (Söyler ve ark., 2018, s. 387). Ayrıca, 2013-2019 yıllarında H. Oy tarafindan yürütülen yüzey araştırmalarında Altıntaş Höyük, Ada Höyük ve Mercimeklik Tepe gibi yerleşimlerde bölgenin Geç Neolitik ve Erken Kalkolitik Çağa ait çanak çömleklerle temsil edilen yeni alanlar keşfedilmiştir (Oy, 2017, s. 340-353; Oy, 2019, s. 19-26).

2017 yılında başlayan Uşak Protohistorik Dönem Yüzey Araştırmaları Projesi'nin (UPDAP) ilk üç sezonu yaygın yüzey araştırmaları (extensive survey) yöntemiyle gerçekleştirilmiştir. Banaz ve Merkez ilçelerinde yürütülen araştırmalarda öncelikle daha önce tespit edilmiş buluntu yerleri incelenmiştir. Eldeki verilere göre oluşturulan yerleşim şablonlarının irdelenmesi yeni buluntu yerlerinin keşfedilmesine olanak sağlamıştır. Projenin ilerleyen yıllarında seçilmiş buluntu yerlerinde yoğun yüzey araştırmaları (intensive survey) yapılarak dönem ve lokasyon odaklı sorulara cevaplar aranması planlanmaktadır. Araştırmalar boyunca birçok prehistorik ve protohistorik yerleşim tespit edilmiştir (Yılmaz, 2019; Y1lmaz ve ark. 2019). Makaleye konu olan Düzkışla Höyüğü bu keşiflerden sadece birisidir. Düzkışla'dan elde edilen buluntular Batı Anadolu Neolitik ve Erken Kalkolitik yerleşmelerinden tanınan buluntuların birçoğunu içermektedir: Yontmataş dilgiler, mermi biçimli çekirdekler, yassı baltalar, mermer kaplar, boyalı çanak çömlek, sapan taneleri, steatopik figürin ve konik figürin gibi. 
Alandan elde edilen buluntular hem Geç Neolitik hem de Erken Kalkolitik özellikleri göstermektedir. Düzkışla Höyüğü'nden şimdiye kadar mutlak bir tarihlendirme elde edilmediği için ve Geç Neolitik- Erken Kalkolitik buluntularının birbirine benzemesi nedeniyle çoğu zaman Geç Neolitik ile Erken Kalkolitik arasında net bir ayrım yapmak zordur. $\mathrm{Bu}$ nedenle, bu makalede "Geç Neolitik-Erken Kalkolitik" terimi kullanılacaktır (Çilingiroğlu, 2012, s. 9-10).

\section{Coğrafi Tanım ve Yerleşimin Konumu}

UPDAP kapsamında 2019 yılında keşfedilen Düzkışla Höyüğü, Uşak il merkezinin doğusunda yer alan Banaz ilçesinde yer alır (Harita). Banaz'ın sınır bölgeleri dağlık (ODS $1250-1350 \mathrm{~m}$ ) arazi olmakla birlikte merkezi bölümleri ovalardan (ODS 850-900 m) oluşmaktadır. Her ikisinin arasındaki bölgelerde ise engebeli ancak yerleşime uygun alanlar bulunmaktadır. İlçenin kuzeyinde Murat Dağı, güneydoğusunda Bulkaz Dağı uzanmaktadır. Murat Dağı'ndan doğan ve Büyük Menderes'in kollarından birisi olan Banaz Çayı, bölgenin en önemli akarsuyudur (Kara, 2010, s. 1). Çamsu köyünden Banaz’a kadar uzanan Höyükdere ve Gürlek Çayı, kuzeydoğudan gelen Kumocağıdere ve Hamamçayı, doğudan gelen Ahat Çayı ve kuzeyden gelen Aktaş ile Banaz Çayı vadileri boyunca rastlanan Kuvaterner dönemine ait yeni alüvyonlar da olasılıkla yerleşim için yer seçiminde önemli etkenlerden olmuştur (Yalçınlar, 1955, s. 68-69). Verimli tarım arazileri, barınmaya elverişli karstik oluşumlar, çevrede yer alan maden kaynakları ve önemli yol güzergâhlarının (Deniz vd., 2014, s. 390) üzerinde yer alması, çağlar boyunca yerleşim için tercih edilmesinde belirleyici diğer etkenler arasında sayılabilir.

2017 yılında başlayan proje kapsamında Banaz'ın doğu bölümündeki dağlık alan ile ovanın bir kısmı çalışıldı. Bu kapsamda, Banaz ilçesinin güneydoğu sınırında yer alan Düzkışla köyünde araştırmalar gerçekleştirilmişti (Yılmaz, 2019, s. 431). 2019 yılında, Banaz'da henüz araştırmadığımız köyler taranırken, Düzkışla halkından alınan bilgiler doğrultusunda, köyün yaklaşık 2 km kuzeydoğusunda prehistorik dönemlere işaret eden bir buluntu yeri ile karşılaşıldı (Resim 1). Toprak bir yolla ulaşılan arkeolojik alan, Tapu Kadastro kayıtlarında ve 1/25000'lik paftalarda “Ahlatlı Mevkii” olarak geçmektedir. Yerleşimin konumu, yukarıda dağlık coğrafya olarak bahsettiğimiz sahaya denk düşmektedir (Kara, 2010, Şekil 1.5). Düzkışla Höyügü ${ }^{1}$ olarak adlandırılan yerleşim yaklaşık 90x100 m'lik (ykl. 1 ha) bir alanı kaplamaktadır. Güneydoğusundan, mevsimlik akan Kurucaoluk Deresi geçmektedir. Yerleşim, dere kotundan kuzeye doğru 16 m yükselen, konglomera formasyonundan oluşan yamaç üzerine kurulmuştur. Güneybatıya doğru Kurucaoluk Deresi'nin oluşturduğu vadiler boyunca Yazıtepe, Ayvacık ve Kavacık köyleriyle bağlıyken; doğuda Dolayköy Deresi ve mevsimlik derelerin parçaladığı arazilerden Ahırhisar/Yeşilhisar üzerinden ulaşımın sağlandığı bir noktada yer almaktadır.

1 Düzkışla Höyük Koordinatları: 35 S 752214 D / 4286581 K, Rakım: 1291,5 m. 
Yerleşim yeri seçiminde en az yukarıda bahsedilen özellikler kadar önemli diğer bir konu hammadde kaynaklarıdır. Neolitik ve Kalkolitik Çağ insanı için önemli hammadde kaynaklarından biri taştır. Düzkışla Köyü ve etrafında Üst Miyosen-Pliyosen yaşlı kireç taşları yaygındır (Kara, 2010, s. 9). Ancak eldeki veriler, alet yapımında genellikle andezit, bazalt, mermer, çakmaktaşı ve obsidyen tercih edildiğini göstermektedir. Yerleşime en yakın andezit kaynakları $14 \mathrm{~km}$ kuzeyde yer alan Sümbül Tepe ve Karaköse civarında görülmektedir. Bazalt, Bulkaz Dağı'nın kuzeydoğu eteklerinde, höyüğe 18 km uzaklıktaki Karanlıcak Tepe civarında görülmektedir (Atasoy, 2017, s. 23, Harita 8). Yerleşime en yakın ve en eski mermer yatakları ise höyüğe sadece 7-8 km uzaklıktaki Yazıtepe Köyü'nün güneyi boyunca geniş bir alanda karşımıza çıkar (Kara, 2010, s. 7). Çakmaktaşı bölgede yaygın olarak bulunurken en büyük kaynağın höyüğe $35 \mathrm{~km}$ uzaklıktaki Altıntaş Köyü yakınındaki Çakmaklık Mevkii'nde olduğunu söyleyebiliriz. Bölgede yerel olarak obsidyen bulunmamaktadır. Obsidyen üzerindeki makroskopik gözlemler genel olarak Orta Anadolu, az sayıda da Melos kökenine işaret eder.

\section{Materyal Kültür}

Düzkışla'dan ele geçen buluntulara bakıldığında güneyde Göller Yöresi ve Kıyı Ege Neolitiği ile ortak özellikler gösteren bir malzeme grubu görmek mümkündür. Buluntular arasında boya bezemeli veya yalın açkılı çanak çömlek parçaları en yoğun buluntu grubudur. Çanak çömlek parçalarının dışındaki karakteristik buluntular pişmiş toprak figürinlerdir. Yüzeyde bulunan iki figürinden birisi steatopik tipte, sokma başlı bir kadın figürini parçasıyken; diğeri cinsiyeti belli olmayan konik biçimli bir pişmiş toprak figürindir. Pişmiş toprak buluntular arasında iki adet sapan tanesi de bulunmaktadır. Kireçtaşı, bazalt, andezit ve serpantinden sürtmetaş aletler ve mermer kaplar ile çok sayıdaki obsidyen ve çakmaktaşından yontmataş aletler ise taş buluntular grubunu oluşturmaktadır. Buluntular çanak çömlek parçaları, diğer pişmiş toprak buluntular ve taş buluntular genel başlıkları altında detaylı tanımlanacak ve kıyaslama örnekleriyle tarihlendirme önerisi yapılacaktır.

\section{Çanak Çömlek}

Düzkışla Höyüğü'nden toplanan 104 adet çanak çömlek parçası üzerinde çalışma yapılmıştır. Bu kapsamda çanak çömleklerin hamur grupları katkı türü ve boyutları, yüzey uygulamaları ile fırınlama özellikleri dikkate alınarak oluşturulmuştur. Kilin içindeki mineral parçacıklarının dağılımı açısından bakıldığında yerleşimin bulunduğu bölge, yoğun olarak feldspat, mika ve kuvars grubu mineral parçacıklarından oluşan toprak yapısına sahiptir (Atasoy, 2017, s. 81, Harita 32). Bu durumu çanak çömlek içindeki mika ve kuvars dağılımında da kendini göstermektedir. Morfolojik tipler ise profil özelliklerine göre gruplandırılmıştır. Burada çanak ve çömlek gibi biçimsel tanımlar profil, ağız çapı ve cidar kalınlığı göz önünde bulundurularak yapılmıştır. Son olarak da bezeme ve motif tipleri değerlendirilmiştir. 
Mal grubu özellikleri açısından incelenen çanak çömlek parçaları iki ana kategori altında toplanmıştır: Orta $(0.2 \mathrm{~mm}-0.63 \mathrm{~mm})$ ve kaba $(0.63 \mathrm{~mm}-2 \mathrm{~mm})$ mallar. Alt tipler ise hamur yapısı ve astar renklerine göre oluşturulmuştur. Orta mallar; kırmızı astarlı mallar (OKA), kahverengi hamurlu mallar $(\mathrm{OKH})$, açık kahverengi mallar (OAK), kahverengi astarlı mallar (OKAM), grimsi kahverengi hamurlu mallar (OGKA) ve krem astarlı mallar (OKRA). Kaba mallar iki alt tip altında incelenebilir: Kaba perdahsız mallar (KPM) ve kaba mikalı mallar (KMM).

Kırmızı Astarlı Mallar (OKA): Kırmızımsı sarı (7.5 YR-7/6) ile kırmızı (10 R-5/8; 2.5 YR5/6) renkleri arasında değişen hamur rengine sahiptir. Astar rengi olarak kırmızıdan (2.5 YR- 5/6) kırmızımsı sarı (5YR-6/6) ve koyu kırmızıya (10R-4/6) değişiklik gösteren bir renk aralığı izlenir. Yüzey izleri parlak (yumuşak) perdah ve sert perdahın bir arada kullanıldığını göstermektedir. Hamur özellikleri bölge karakterinden biraz farklıdır. Bu mal grubunda bazı örneklerde altın renkli mika orta boyutta ve yoğun görülür. Orta boyutta ve orta yoğunlukta kum, silt ve kireç ile seyrek kuvars katkılı hamura sahiptir. Yükseltgenmiş ortamda iyi fırınlanmışlardır.

Kahverengi Hamurlu Mallar (OKH): Kahverengi (7.5YR-5/4) hamur renginde, baz1 örneklerde firınlamadan kaynaklanan gri bir öz görülen hamurlara sahiptirler. Hamur içeriğinde bölgenin kil özelliklerini tam olarak yansıtan kaba kuvars, yoğun ince mika ve feldspat görülmektedir. Hamur içeriğindeki yoğun, ince mika bazı örneklerde astar olarak kullanılmıştır. Genellikle yumuşak perdah görülmektedir. Bazı örnekler sert perdahlı, az sayıda da perdahsız örnek vardır. Yüzeydeki alacalanmalardan dolayı kontrolsüz veya açık bir fırınlama süreci geçirdiklerini söyleyebiliriz.

Açık Kahverengi Mallar (OAK): Boyalı bezemeli olanlar açık kırmızımsı kahverengi (2.5 YR-6/4) ve yalın olanları açık kahverengi (7.5 YR-6/4) hamur rengine sahiptirler. Hamur renginde astarlı, genellikle parlak perdahlıdır. Perdahtan dolayı dış görünümlerinde bir ton koyulaşma dikkat çekmektedir. Hamur içeriği bakımından ince-orta boyutlu kum, kuvars ve kireç katkılıdır. Çok seyrek ve ince mika bölgesel özellik olarak kendini göstermektedir.

Kahverengi Astarlı Mallar (OKAM): Açık kahverengi mallar ile benzer hamurözelliklerine sahiptir. İçerik olarak biraz daha yoğun bir kireç katkı görülür. Bölgesel kil özelliklerinin dışında değildir. Asıl fark yüzey uygulamalarında kendini gösterir. Bazen dış bazen de iç yüzeyinde, koyu kahverengi (7.5YR-4/4 ve 7.5YR-5/6) tonlarında değişen görünümünde bir astara sahip mallardır. Parlak perdahları ve pürüzsüz yüzeyleri vardır. Fırınlama genellikle kontrollüdür. Bazı örneklerde gri özlü bir pişirim görülür.

Grimsi Kahverengi Hamurlu Mallar (OGKA): Kahverengi (7.5YR-5/2) ve koyu grimsi kahverengi (10 YR-4/2) renk tonları arasında değișen hamur ve yüzey rengine sahip mallardır. Orta boyutta kum, seyrek kuvars ve feldspat ile ince, orta yoğunlukta mika katkılı hamura sahiptir. Sert ve yumuşak perdah bir arada görülür. Genellikle indirgenmiş bir ortamda firınlanmışlardır. 
Krem Astarlı Mallar (OKRA): İnce, orta yoğunlukta mika ve seyrek kuvars ve kireç katkılı hamur, aslında orta malların genel hamur özelliklerini gösterir. Ancak diğer gruplarda daha yoğun görülen kuvars bu grupta seyrektir. Kırmızımsı sarı (7.5 YR-6/6) hamur rengi baskındır. Dış yüzeylerinde sarı (10 YR-8/6) ile çok soluk kahverengi (10 YR-7/3) tonlarında değişen astar rengine sahiptir. Bazı örneklerde dış yüzeyde krem astar görülürken çanak formlarının iç yüzeyinde kahverengi astarlı mallarda görülen astar uygulanmaktadır. Ayrıca bu grupta genel olarak dış yüzde astar üzerine kahverengi veya kırmızımsı kahverengi boya ile yapılmış bezemeler görülmektedir.

Kaba Perdahsız Mallar (KPM): Çok kaba ve orta yoğunlukta görülen kuvars ve silt taşı, orta yoğunlukta bitkisel katkılı hamura sahiptir. Seyrek mika görülen hamur, açık kahveden koyu griye giden renk tonlarındadır. Düzensiz açık ateşte bir firınlama geçirdiklerini söylemek mümkündür. Orta derecede pişirilmiştir. Bu mal grubunda perdah görülmemektedir. Kaba katkıları ve yüzeyde izlenen ikincil ateş izlerinden dolayı pişirme kabı olarak kullanıldıkları düşünülmektedir.

Kaba Mikalı Mallar (KMM): Kaba malların hamur özelliklerine sahiptir. Çok yoğun görülen mika hem hamura katkı olarak eklenmiş hem de bazı örneklerde dış yüzey üzerinde ince bir astar olarak uygulanmıştır. Kuvars, seyrek ama kaba bir katkı olarak kendini gösterir. Yüzey uygulaması olarak ince bir astar görülürken perdah yoktur. Düzensiz renklenmeden ötürü kontrolsüz bir fırınlama süreci geçirdikleri söylenebilir.

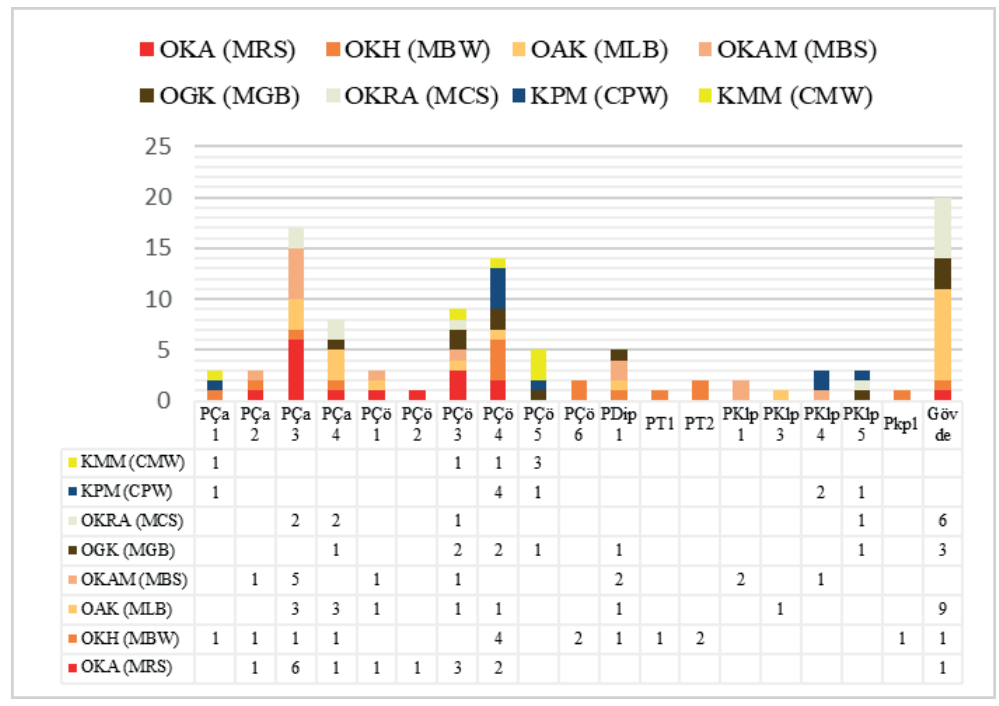

Tablo 1. Mal ve Form İlişkisi. 
Form özellikleri dikkate alındığında çanak çömlek repertuarı, çanaklar, derin çanaklar ve çömlekler olmak üzere üç ana grupta incelenebilir. Genel grupların alt tipleri gövde, boyun veya ağız biçimine göre oluşturulmuştur. Ayrıca dip, kulp ve kapak gibi eklentiler de kendi içinde gruplanmıştır. Son olarak, bezemeli gövde parçaları, bezeme ve uygulanış biçimine göre gruplara ayrılmıştır. Küresel gövdeli, basit ağız kenarlı çanaklar (PÇa1) (Resim 2/13); küresel gövdeli, basit ağız kenarlı derin çanaklar (PÇa2) (Resim 2/4-6); dışa çekik ağız kenarlı derin çanaklar (PÇa3) (Resim 2/7-22); dışa çekik ağız kenarlı derin çanaklar (PÇa4) (Resim 3/1-7) ve çanak formlu kaplar da sık görülen alt tiplerdir. Özellikle dışa eğik ağız kenarlı derin çanaklar, Batı Anadolu'nun Geç Neolitik-Erken Kalkolitik Çağ buluntusu veren yerleşimlerinde yaygındır. Benzer örnekleri ışığında genellikle 'S' profilli ve küresel alt gövdeye sahip bu formlar, ağız çapları ve cidar kalınlıklarından dolayı derin çanak olarak tanımlandı. Genellikle ince bir cidara sahip dışa eğik ağız kenarlı derin çanaklar kırmızı astarlı (OKA) ve krem astarlı (OKRA) mal özellikleri göstermektedir.

Çömlek formları arasında: Daralan ağızlı küresel çömlekler (PÇö1) (Resim 3/8-10); boyunsuz, düz kesilmiş küt ağız kenarlı çömlekler (PÇö2) (Resim 3/11), kısa boyunlu, basit ağız kenarlı çömlekler (PÇö3) (Resim 3/12-22), silindir boyunlu çömlekler (PÇö4) (Resim 4/1-15), dışa eğik ağız kenarlı, geniş boyunlu çömlekler (PÇö5) (Resim 4/16-20), pervaz ağızlı çömlekler (PÇö6) (Resim 4/21-22) yer almaktadır. Çömleklerin alt tiplerinde kısa boyunlu, basit ağız kenarlı ve silindir boyunlu örnekler öne çıkmaktadır. Özellikle 15 ile $34 \mathrm{~cm}$ arasında değişen ağız çaplarına sahip silindir boyunlu çömleklerin işlevlerini farklı değerlendirmek gerekir. Cidar kalınlıkları neredeyse tamamında aynı olan çömleklerin dar ağızlıları sıvı saklama amaçlı, geniş olanları ise kuru gıdanın depolanmasında kullanılmış olabilir. Dışa eğik ağız kenarlı, geniş boyunlu çömleklerde ise kaba mikalı mal özellikleri gösteren örnekler fazladır. Bu tip çömleklerin astarsız, perdahsız ve özensiz yapısı ile kaba hamur özellikleri günlük kullanımlarına işarettir.

Eldeki dip biçimleri ise basit düz diplerden (PDip1) ibarettir (Resim 5/1-6). Sadece kahverengi astarlı mal (OKAM) özellikleri gösteren bir örnek literatüre disk dip (disc base) olarak geçen gruba yakındır (Resim 5/3). Buluntu topluluğu içinde çeşitli kulp tipleri tespit edilmiştir. Bunları şu şekilde sıralayabiliriz: Hayvan biçimli ip delikli tutamak (PT1) (Resim 5/7), dikey ip delikli tutamak (PT2) (Resim 5/8-9), oval kesitli sepet kulplar (PKlp1) (Resim 5/10-11), oval kesitli yatay kulplar (PKlp3) (Resim 5/12), oval kesitli dikey kulplar (PKlp4) (Resim 6/1-4), yuvarlak kesitli dikey kulplar (PKlp5) (Resim 6/5-7). Kulp ile birlikte ele geçen ağız profilli parçalar sadece oval kesitli sepet kulplardır. Diğer kulp parçalarında ağız kenarları korunmamış olsa da benzer örneklerden hareketle, silindir boyunlu çömleklerde ip delikli kulplar kullanılmış olmalıdır. Kronolojik dizinde ip delikli tutamakların Neolitiğin erken dönemlerinden itibaren çeşitli boyutlarda ve biçimlerde kullanıldı̆̆ını görmekteyiz. Çanak çömlek parçaları arasında bir adet kapak parçası da vardır. Kapak, pervaz ağızlı kaplardan biri ile form ve mal özellikleri açısından benzemektedir (Resim 6/8; Resim 4/22). 
Toplam boya bezemeli parça sayısı 26'dır. Bunların 20 tanesi gövde parçası, 6 tanesi ise ağız parçasıdır. Boya bezemeler genellikle krem astar üzerine koyu kahverengi (Resim 6/9-12), krem astar üzerine kırmızımsı kahverengi (Resim 6/13-15), kendi astarı üzerine kırmızımsı kahve (Resim 6/18-27) ve grimsi kahverengi astar üzerine siyah (Resim 6/28) boya ile yapılmıştır. Dışa çekik ağız kenarlı derin çanaklar ve dışa çekik ağız kenarlı derin çanakların ağız kenarının dış ve bazen şerit halinde içinde boya bezeme görülmektedir (Resim 2/7-8, 18-19; Resim 3/1, 6). Bezemeli kapların motif repertuvarı çok zengin değildir. Yatay ve dikey şeritler, balıksırtı, iç içe açı ile kafes tarama motifleri ile düzensiz geometrik unsurlar bezeme öğesi olarak kullanılmıştır.

İncelenen çanak çömlek parçaları içinde bazı form, mal ve bezeme özellikleri bölgelerarası benzerlikler ve tarihlendirme konusunda ipuçları vermektedir. Kıyaslama yoluyla vermeye çalışacağımız göreli tarihleme, bazı form ve mal özelliklerinin Erken Neolitik Çağ'dan Erken Kalkolitik Çağ'a kadar kullanılıyor olması nedeniyle oldukça zordur. Ancak Neolitik'in belli evrelerinde tipik olarak görülen morfolojik özelliklere dayanarak yerleşimin göreli tarihlendirmesine genel hatlarıyla katkı sağlamaya çalışacağız.

$\mathrm{Bu}$ karşılaştırmaları yaparken öncelikle kazısı yapılmış merkezlerin buluntularından yararlanıldı. Daha sonra aynı etkileşim bölgesindeki yüzey araştırmalarıyla elde edilmiş çanak çömlek grupları değerlendirmeye alınmıştır. Bu kapsamda en güçlü etki alanının Göller Yöresi olduğunu söyleyebiliriz. Hacılar'ın IX-VI arasındaki tabakaları MÖ 64106250 tarihlerine ait olup bölgenin Geç Neolitik Çağ kültürü olarak değerlendirilir (Thissen, 2010, s. 272). Bu tabakalarda daralan ağızlı (hole-mouth) çömlekler ile dikine ip delikli tutamaklar baskındır. Düzkışla Höyüğü'nde de görülen dikine ip delikli tutamakların (Resim 5/8-9) benzer örneklerine Hacılar IX'dan itibaren rastlanmaktadır (Mellaart, 1970, s. 243/10). Bu tutamak biçimi Hacılar'ın Erken Kalkolitik Çağ tabakalarına geçişte azalır, Tabaka IIB-A ile dikey çift kulp yoğunlaşır ve Tabaka I'de dikine ip delikli kulplar tamamen ortadan kalkar. Yine Düzkışla'da örneklerini gördüğümüz sepet kulpların (Resim 5/10-11) benzerlerine de Hacilar IX'da rastlanır (Mellaart, 1970, s. 245/39). Bununla birlikte daralan ağızlı çömlekler, Hacılar'ın erken katlarında görülürken; sonrasında yerini 'S' profilli çömleklere bırakmaktadır. Düzkışla'da en baskın profil gruplarından biri olan dışa eğik ağız kenarlı çanaklar (PÇa3), Hacılar VI'dan itibaren görülür. Fakat özellikle boya bezemeli örnekler daha çok Hacılar V-II arası özelliklerini karşılamakta ve bu haliyle yaklaşık olarak MÖ 6210-6040'e tarihlenmektedir (Mellaart, 1970: s. 272-349). Düzkışla Höyüğü’neki küresel gövdeli, basit ağız kenarlı çanaklar (PÇa1) (Resim 2/1-3) ve küresel gövdeli, basit ağız kenarlı derin çanaklar (PÇa2) (Resim 2/4-6) ile içe kapanan ağızlı çömlekler (Resim 3/810, 16-21) Höyücek’in MÖ 6380-6210 arasına tarihlenen ‘Erken Yapılar Evresi (EYP)’nde 
görülmektedir² ${ }^{2}$ Dışa eğik ağız kenarlı (PÇa3) ve kahverengi astarlı çanakların benzerleri ise Höyücek Tapınak Dönemi’nde (TD) (MÖ 6280-6080) görülmektedir (Duru ve Umurtak 2005, Levha 54/1-5).

Göller Yöresi'nden kıyaslama yapacağımız diğer yerleşim Kuruçay Höyük’tür. Kuruçay 13. katıyla başlayan ve Erken Kalkolitik Çağ (7. kat) ile neredeyse ortadan kalkan dikine ip delikli tutamakların benzerleri Düzkışla'da da bulunmaktadır. Ayrıca Düzkışla'da görülen hayvan başı biçiminde ip delikli kulplar, Kuruçay’ın 12. katında başlamış, 11. katta devam etmiş ve Erken Kalkolitik Çağ tabakalarına (7. kat) kadar görülmektedir (Duru, 1994, s. 33 Levha 59/11, Levha 164/3, Levha 197/6). Düzkışla'da dışa dönük ağız kenarlı çanakların benzerleri (PÇa4) Kuruçay 11. kat çanak çömleği içinde (Tip 12) karşımıza çıkar. Bununla birlikte daralan ağızlı çömlekler, 11. katta genellikle A türü mal özelliklerine sahip olsa da farklı mal grupları içinde de görülmektedir ${ }^{3}$. Boyalı çanak çömleklerin motif ve bezeme anlayışı açısından Kuruçay 11. kat ve takip eden katlardaki örnekler, Düzkışla'dan farklılaşmaktadır. Düzkışla' da boyalı çanak çömlek örneklerinde, kabın iç kısmında bezemeye rastlanmamıştır. Kuruçay'da özellikle 'S' profilli kapların ağzındaki şerit bezemeler Düzkışla' da nadiren görülür (Resim 2/18). Kuruçay’ın erken katlarındaki kabartmalı çanak çömlek örnekleri ile içe çıkıntı yapan ağız kenarlı kaplarla Düzkışla repertuvarında karşılaşılmamıştır.

Bu bölgedeki diğer bir önemli yerleşim olan Bademağacı Höyük’te bazı benzerlikler izlenmektedir. Genel anlamda, EN I ve EN II çanak çömlek repertuvarının içinde en dikkat çekici özellik boya bezemenin yok denecek kadar az olmasıdır. Bademağacı'nın EN I/6 katında pervaz ağızlı kapların ortaya çıkışı bölge ve Batı Anadolu için ortak bir nokta olarak alınabilir (Duru, 2007, s. 347, Fig. 64b/6; Duru ve Umurtak 2019, Levha/Plate 33/3). Düzkışla Höyük dışa açılan ağız kenarlı çanakları (PÇa4) ve 'S' profilli kaselerin benzerleri daha nitelikli bir çanak çömlek üretiminin görüldüğü Bademağacı EN II’de karşımıza çıkar. Bademağacı EN II tabakası Hacılar IX-VI tabakaları ile çağdaş olarak yorumlanır. Geç Neolitik ve Erken Kalkolitik Çağ tabakalarında kırmızı üzerine krem veya kırmızı üzerine beyaz boya ile yapılmış çanak çömleklerin varlığı rapor edilmiştir. Göller Yöresi ile koşut olarak omurgalı çanakların içine ve dışına boya ile yapılan çizgisel bezemeli parçalar dikkati çeker (Duru, 1996, s. 786, 795, Levha 14). Düzkışla' da az sayıda benzer örneklerini gördüğümüz bu tür çanak çömlekler, Hacılar V-II ve Kuruçay 10-7. tabaka çanak çömleği ile yakın benzerlikler göstermektedir.

Düzkışla çanak çömleği ile yakınlık gösteren diğer bir bölge Yukarı Menderes Havzası'dır. Bölgede gerçekleştirilen yüzey araştırmalarında Neolitik ve Erken Kalkolitik Çağ'a tarihlenen 18 yerleşim tespit edilmişti (Dedeoğlu, 2014, 36; Dedeoğlu ve Ozan 2016).

2 Höyücek Mal 1, Mal 2 ve Mal 3 hamur özellikleriyle çanaklar için Duru-Umurtak 2005: Levha 33-34, 35/6-9, 38/2, 42/2-3; çömlekler için Duru-Umurtak 2005: Levha 35/1-3, 37/1-2, 38/7, 40/1, 7-8, 42/5-8.

3 Dışa açılan ağız kenarlı çanaklar için Duru 1994: Levha 55/8-14. 
Yerleşimlerden elde edilen çanak çömlekler arasında Göller Yöresi yerleşimleriyle benzer bir şekilde, genellikle Neolitik Çağ tabakalarında yoğun görülen dikine ip delikli kulplar ve Erken Kalkolitik Çağ boyunca görülen boyalı örnekler görülmektedir. Düzkışla'da en yaygın formlardan olan dışa çekik ağız kenarlı derin çanaklar (PÇa3) ve kısa boyunlu, basit ağız kenarlı çömleklerin (PÇö3) paralellerine, Yukarı Menderes Havzası'nda rastlanmıştır (Dedeoğlu, 2014, Figür 2/4-17, Figür 4/1-10, 17-25).

Bölgedeki yüzey araştırmalarından ziyade, Ekşi Höyük’te devam eden kazı çalışmaları, havzanın Neolitik ve Kalkolitik Çağ süreçlerini aydınlatan bilgiler üretmektedir (Dedeoğlu ve ark., 2017, 389; Dedeoğlu ve ark., 2018, 553). Ekşi Höyük’te MÖ 6700-6500, MÖ 6400-6000 ve MÖ 6000-5700 aralıklarına tarihlenen üç yapı katı söz konusu sürece dair mimari, çanak çömlek ve küçük buluntuları sunmaktadır. Özellikle MÖ 6400-6000 arasında tarihlendirilen evrede az sayıda boyalı örneğin yanında ağırlıklı olarak kırmızı ve kahverengi astarlı monokrom çanak çömlekler ele geçmiştir. Bu evreye ait çanak çömlek formları arasında Düzkışla'daki kırmızı astarlı dışa eğik ağız kenarlı çanaklar (PÇa3) (Resim 2/910, 14, 16-17) ve kısa boyunlu, basit ağız kenarlı çömlekler (PÇö3) (Resim 3/19,21-22) ile benzer grupları görmekteyiz (Dedeoğlu vd., 2017, Çizim 3; Dedeoğlu vd., 2018, s. 566, Figür 9). MÖ 6000-5700 arasında tarihlendirilen yapı katına ait çanak çömlek arasında, özellikle Düzkışla'nın boyalılarıyla paralel örnekler görülmektedir (Dedeoğlu ve ark., 2017, Çizim 2; Dedeoğlu ve ark., 2018, s. 564, Figür 6). Son olarak, Ekşi Höyük'ün aynı tabakasında ortaya çıkan hayvan biçimli ve ip delikli tutamaklar Düzkışla'daki örnekleri andırmaktadır (Dedeoğlu ve ark., 2018, s. 564, Figür 6).

Düzkışla'daki çanak çömleklerin mal ve form açısından yakın paralellerine Ulucak, Yeşilova, Ege Gübre ve Çukuriçi gibi İzmir çevresindeki höyüklerde rastlamaktayız. Ulucak IV'te (Çilingiroğlu ve ark., 2012, s. 143) ve Yeşilova Neolitik III (3-5)'te (Derin, 2012, s. 180) baskın mal grubu olan kırmızı astarlı perdahlı mallar Düzkışla'da da benzer form özellikleriyle karşımıza çıkmaktadır. Düzkışla' daki kırmızı astarlı ve mika katkılı boyunsuz, düz kesilmiş küt ağız kenarlı çömlekler (PÇö2), Yeşilova Neolitik III.5'te karşımıza çıkmaktadır (Derin, Ay ve Caymaz 2009, Fig.8/34-35). Benzer çömleklere Ulucak IVk'da rastlanır (Çilingiroğlu, 2012, Plate 55/1,3). Ege Neolitiğinin başka bir temsilcisi olan Ege Gübre yerleşiminde de aynı tip çömlekler karşımıza çıkmaktadır (Sağlamtimur, 2012, fig.10/1-2). Ayrıca Batı Anadolu Neolitiğinde yaygın olarak bulunan kırmızı astarlı, 'S' profilli çanaklar Düzkışla'da olduğu gibi Ege Gübre 4-3a-b yerleşiminde de ele geçmiştir (Sağlamtimur, 2012, fig.12). Son olarak Çukuriçi’nde de karşımıza çıkan benzer kırmızı astarlı ve 'S' profilli çanaklar Ulucak IV, Yeşilova III ve Ege Gübre yerleşimlerinden elde edilen çanak çömleklerle çağdaştır (Galik ve Horejs 2011, s. 88). Batı Anadolu Neolitiğinde görülen baskı bezeklilerin benzerlerini Düzkışla Höyük’te göremiyoruz. Gene Düzkışla'da göremediğimiz başka bir form ise uzun boyunlu çömleklerdir. Her iki malzeme grubunun 
da MÖ 6000'lardan itibaren Batı Anadolu'da ortaya çıktığı bilinmektedir. Düzkışla'da söz konusu özelliklerdeki parçaların ortaya çıkmayışı yerel çanak çömlek geleneğinin ve yemeiçme kültürünün bir sonucu olabileceği gibi, yüzey araştırması sırasında toplanan örneklem grubunun bu tipte parçaları tesadüfen içermiyor oluşuyla da ilgili olabilir.

Düzkışla ile etkileşim görülen başka bir bölge, İç Batı Anadolu'nun kuzey bölümü yani Porsuk ve Sakarya Nehirleri'nin suladığı geniş düzlükler ile dağlık arazideki yerleşimlerdir. Keçiçayırı'ndaki çanak çömlek buluntuları, karşılaştırmalı kronolojiye göre MÖ 6600-6300 arasına tarihlenen Neolitik yerleşime işaret etmektedir (Sarı ve Akyol 2019, s. 150). Söz konusu yerleşimde öne çıkan bazı mal grupları ve formların benzerlerine Düzkışla Höyük’te de rastlamaktayız. Özellikle kısa boyunlu, basit ağız kenarlı çömlekler (PÇö3) (Resim 3/14-15), Keçiçayırı'nda koyu yüzlü ve kırmızı astarlı örnekleriyle çok yakın benzerlik göstermektedir (Sarı ve Akyol 2019, Pl.2.25-26). Aynı zamanda pervaz ağızlı çömleklerin (PÇö6) (Resim 4/21-22) çok yakın benzerleri de dikkati çekmektedir (Sarı ve Akyol 2019, P1.1.5-6). Bölgedeki diğer anahtar yerleşim, Eskişehir Ovası'nın batısında yer alan Demirci Höyük'tür. Demirci Höyük’te Neolitik ve Kalkolitik Çağlar'a tarihlenen çanak çömlekler yedi mal grubu altında değerlendirmiştir (Seheer, 1987, s. 18-22). Bunlardan A-E tipi mallar Geç Neolitik ile Erken Kalkolitik Çağlar arasına; F-G tipi mallar ise Geç Kalkolitik Çağ'a tarihlendirilmiştir. Düzkışla Höyük çanak çömleği içinde A, B, D ve E tipi mal özellikleri gösterenler yoğunluktadır. Özellikle mika şist katkılı A tipi (Ware A) mallar çeşitli form özellikleriyle Düzkışla'da karşımıza çıkar (Resim 2/3, Resim 4/2-3,5, 14, 20, Resim 6/1, 3, 7). Demircihöyük B tipi mallar (Ware B) içindeki pervaz ağızlı çömlekleri (Seheer, 1987, Tafel 1/21, 23), Düzkışla'da çok yakın paralelleriyle görmekteyiz (Resim 4/21-22). Form, mal grubu ve bezeme özellikleri açısından Düzkışla Höyük çanak çömlekleriyle (Resim 2/78, 18-19, Resim 3/1, 6, Resim 6/9-28) kıyaslanabilecek diğer grup ise D tipi mallardır. Bu grup, krem üzerine kırmızı boya ile yapılmış bezemesi, 'S' profilli çanaklarıyla Göller Yöresi Erken Kalkolitik Çağ çanak çömleği ile koşuttur (Seheer, 1987, Tafel 8-9).

Son olarak Uşak ve yakın çevresinde gerçekleştirilen yüzey araştırmalarıyla tespit edilen bazı yerleşimler hem kıyaslama için hem de kültürün hareket noktalarını anlamak için önemlidir. Afyonkarahisar'ın ilçelerinde ve hatta Uşak'ın Sivaslı ilçesinde yüzey araştırmaları gerçekleştiren Ö. Koçak, bazı Geç Neolitik ve Erken Kalkolitik Çağ yerleşimleri rapor etmiştir. Bu yerleşimlerden öne çıkanlar: Sinanpaşa/Eyice Höyük, Çobanlar/Pani Höyük (Koçak ve Bilgin 2010, s. 23), Sandıklı/ Bektaş Üyük Tepe ve Üçin (Koçak ve Bilgin 2013, s. 31), Hocalar/Asarın Tepe ve Devlethan (Koçak ve Bilgin 2012, s. 1) yerleşimleridir. Özellikle Göller Yöresi çanak çömleğiyle koşut çanak çömlek repertuvarına sahip Üçin Höyük buluntuları (Koçak ve Bilgin 2013, Res.12/1, 5, 6-7), Düzkışla boyalılarına benzemektedir (Resim 2/1, 18-19, Resim 6/12). Üçin, Göller Yöresi'ne yakınlığı ve kültürün kuzeyle ilişkisi bağlamında stratejik bir konumda yer alır. Düzkışla Höyük'e oldukça yakın olan Asarın Tepe 
(5,5 km) (Koçak ve Bilgin 2012, Resim 6, Çizim 3), Devlethan (15 km) (Koçak ve Bilgin 2012, Resim 7, Çizim 4) ve Eyice Höyük (28 km) (Koçak, 2010, Res.18-22) çanak çömleği de Göller Yöresi karakterinde, mal ve form açısından Düzkışla Höyük’le benzerdir. Farklı ekipler tarafından Uşak’ta gerçekleştirilen yüzey araştırmalarında Düzkışla Höyük'e yakın bazı yerleşimler tespit edilmiştir. Düzkışla’nın $11 \mathrm{~km}$ kuzeyinde Mercimeklik Tepe (Oy, 2019, Levha 4/43-44) ve 8 km güneybatısındaki Ada Höyük’te (Oy, 2019, Levha 1-3) ele geçen bazı çanak çömlek parçaları, Düzkışla'daki kırmızı astarlı (OKA) ve kahverengi astarlı mallar (OKAM) ile krem astar üzerine kırmızı boyalı çanak çömlekler ile yakın benzerlik göstermektedir.

\section{Diğer Pişmiş Toprak Buluntular}

Düzkışla'daki kronolojik dizine yerleştirilmeye çalışılan buluntulara destek sağlayacak başka bir buluntu grubu, pişmiş toprak figürinler ve sapan taneleridir;

Alandan toplam iki figürin ele geçmiştir. Ele geçen steatopik yapıdaki figürin parçasının karın ve göğsünün bir kısmı sağlam durumdadır (Resim 7/1). Hamur; açık kahverengi, temiz ve ince taneli, kırmızı astarlı ve perdahlıdır. Göbek ve meme sarkık olarak tasvir edilmiştir. Göbek deliği belli edilen figürinin kol veya eli ile ilgili bir iz görülmemektedir. Bu durum figürinin kollarının yanda verildiğine, bir elinin göğüs üzerinde olabileceğine veya kollarının küt şekilde verilmiş olduğuna işarettir. Boyun kısmından sırta doğru giden bir yuva bulunmaktadır. Bu da Geç Neolitik Çağ figürinlerinde izlenilen sokma baş yuvasıdır. Sokma başlı figürinler olarak değerlendirilen bu tipte, kemik veya taştan yapılan başlar da vardır. Son derece kaliteli bir işçiliğe sahip figürinin benzerlerini Çatalhöyük, Çukurkent, Hacılar, Kuruçay, Höyücek ve Bademağacı'nda görmekteyiz. Düzkışla örneği Çatalhöyük’te II. tabakada ele geçen figürinlere stilistik açıdan benzemekle beraber, en yakın benzerleri Hacılar VI. tabakada karşımıza çıkar. Ayakta duran figürinlerden (Mellaart, 1970, 489/211, 490/212) ziyade oturan figürinler, Düzkışla örneklerine daha yakın anatomik özellikler sergiler (Mellaart, 1970, 492/, 493/215). Anatomik özelliklerin işleniş biçimi ve ellerin pozisyonu gibi detaylar Düzkışla figürininin de oturur bir pozisyonda tasvir edildiğine işaret eder. Mellaart'ın Hacılar'daki figürinleri değerlendirdiği yayında VI. tabaka için karşılaştırma örneği olarak kullandığg ve Banaz Ovası'ndaki Kayirli Köy’den ele geçtiğini belirttiği bir figürin, Düzkışla örneğiyle yakın benzerlik gösterir ${ }^{4}$. Sol eli göğsünde, sağ eli dizinin üzerinde verilmiş olan figürinin yakın benzerlerine Çatalhöyük'ün II. tabakasında rastlamaktayız (Bilgi, 2012, s. 92/152, 154). Benzer özelliklere sahip olan Çukurkent'ten ele geçen figürin aynı zamanda sokma başlı bir örnektir (Bilgi, 2012, s. 92/153). Bilgi (1980,s. 2), Çukurkent figürinini Hacılar VI figürinleriyle kıyaslayıp Geç Neolitik Çağ olarak tarihler. Aynı yayında Uşak/Banaz'da Alıçlı Höyük’ten iki buluntuda bahsedilir. Birincisi steatopik

4 Hacılar VI ile Çatalhöyük II figürinlerine benzetmektedir. Mellaart, 1970: s. 173-174; 232/CVXXIII 
yapıda ve oturur biçimdeki bir figürinin belden aşağısıdır (Bilgi, 1980, Levha/Plate III/Res./ Fig.6). Diğer buluntu ise boyunlu bir baştır (Bilgi, 1980, Levha/Plate III/Res./Fig.7). Bu tip başlar sokma başlı olarak tanımlanan figürinlerin başı olarak yorumlanır. Gözleri iri, saç detayları belirgin olarak verilen başın arka bölümünde, belki de bir saç aplike etmek için açıldığı düşünülen üç adet üçgen biçimli çukur görülmektedir. Bilgi, figürinlerin Hacılar'ın VI. tabakasından ele geçen örneklere benzerliğinden dolayı Geç Neolitik Çă̆ tarihini önermektedir (Bilgi, 1980, s. 4). J. Mellaart tarafından, Hacılar kitabında kıyaslama örneği olarak yayınlanan ve bugün Afyonkarahisar Müzesi'ndeki steatopik figürinin buluntu yeri Banaz/Kayirli Köy olarak geçmektedir (Mellaart, 1970, s. 232, CLXXIII ). Ancak Uşak’ta ne bu isimde bir köy ne de höyük vardır. Yine Ö. Bilgi tarafından (1980, s. 3) Belleten'de yayınlanan bir makalede değerlendirilen iki figürinin buluntu yeri olarak Banaz/Alıçlı Höyük verilmiştir. Banaz'da veya Uşak sınırlarında Alıçlı Höyük olarak kayda geçmiş bir höyük bulunmamaktadır. Mellaart tarafından bahsedilen 'Kayirli Köy’ Düzkışla Köyü’nün 7 km batısındaki Kaylı Köyü ve Bilgi’nin bahsettiği Alıçlı Höyük’ün ise Alıçlı Mevkii’nde yer alan Ada Höyük olabileceğini önerebiliriz. Bu düşünceyle Düzkışla ile yakın benzerlikler görülen bu buluntular küçük bir coğrafi bölge içinde değerlendirilebilir. Birbirine 6-7 km mesafedeki Düzkışla ve Ada Höyük arasındaki diğer buluntular da bu varsayımı desteklemektedir. Höyücek Kutsal Alanlar Dönemi yerleşmesinden ele geçmiş kemik başlı, çuval tipli idollerle birlikte Düzkışla'daki figürine benzer steatopik figürinler de ele geçmiştir (Duru ve Umurtak 2005, Levha/Plate 122-125). Kuruçay'da, ayakta duran ve en eskisi 11. kat'1n alt evresinden (Duru, 1994, s. 60, Levha 185/1) gelen örnekle birlikte Erken Kalkolitik Çağ'a kadar uzanan bir aralıkta figürin parçaları ele geçmiştir (Duru, 1994, Levha 185-193). Benzer yapıdaki az sayıda figürin Bademağacı Höyük’te EN II ile Geç Neolitik-Erken Kalkolitik Çağ’a tarihlendirilmiştir (Duru ve Umurtak 2019, Levha 118-119). Ö. Koçak tarafından Sivaslı ilçesinde gerçekleştirilen yüzey araştırmaları sırasında, Köyaltı Hüyükler Mevkii'nden de benzer bir figürin bulunmuştur. Steatopik yapıda, sokma başlı, dizleri üzerine oturmuş ve sağ el dizinin üzerinde sol el ise göğüs altındadır (Koçak, 2015, s. 357, Resim 3).

Düzkışla Höyük’te steatopik figürinin dışında bir adet konik biçimli antropomorfik figürin ele geçmiştir (Resim 7/2). Kahverengi hamuru (7.5YR-5/4) ve çok ince kırmızı astarı ile (5YR-4/4) Düzkışla seramiklerinin mal grubu özellikleriyle benzemektedir. Elle basitçe şekillendirilmiş figürin stilize edilmiş insanı temsil etmektedir. Konik yapıdaki objenin sadece sağ kulak kısmı kırıktır. Kulak ve burun bir çimdik ile plastik olarak verilirken göz ve ağız kazıma olarak yapılmıştır. Alt bölümü, iç bükey olarak verilmiş bir kaide şeklindedir. Böylelikle serbest durabilen bir figürin halini almıştır. En yakın benzerleri Ürdün'deki eş-Şifiye yerleşmesinde ele geçmiştir. Ain Ghazal, Tell Aswad, Tell Ramad ve Basta gibi yerleşimlerden ele geçen kıyaslama örnekleri ışığında el-Şifiye figürinleri Geç PPNB'ye tarihlenmektedir (Mahasneh ve Bienert 1999, s. 116). Özellikle konik tipte tasvir edilip göz, kulak ve burunun işlendiği 2. grup figürinleri, Düzkışla'dan ele geçen figürin ile yakın 
benzerlik göstermektedir (Mahasneh ve Bienert 1999, s. 114, Fig.5, Tafel 24/A-B ). Bu figürinlerin pişirilmemiş kil objeler olduğu ve istemsiz bir biçimde, yani bir yangın vb. olay sonucunda piştiği önerilmektedir. Ürdün'deki bu arkeolojik alan dışında, Anadolu Neolitik ve Kalkolitik Çağ yerleşimlerinde Düzkışla figürinin paralellerine henüz rastlanmamıştır. Ancak tipolojik olarak benzeri yalnız bir örnekle Demircihöyük’te ele geçmiştir (ObladenKauder, 1996, Tafel 127/10). Erken Tunç Çağı I'e tarihlenen figürin, Düzkışla figürinine konik yapısı ile benzemektedir. Demircihöyük figürini diğer özellikleriyle ETÇ II'de yaygınlaşan disk yüzlü figürinlere benzemektedir. Düzkışla Höyük’te, Erken Kalkolitik Çăg sonrasına ait herhangi bir bulgunun ele geçmediği için şimdilik dönemsel kıyaslamadan çok yapısal kıyaslama yapabiliriz.

Pişmiş toprak buluntuların içinde değerlendirebileceğimiz diğer buluntular sapan taneleridir. Düzkışla Höyük’te iki adet çift konili ve iki adet küresel formda sapan tanesi bulunmuştur. Çift konili sapan taneleri yarım olarak ele geçmiştir (Resim 7/3-6). Yoğun ve kaba kuvars katkılı bir hamura sahip olan sapan taneleri, ikincil bir ateşe, belki de bir yangına maruz kaldığından alacalı bir renklenmeye sahiptir. Küresel sapan taneleri tamdır ve açık kırmızı renklidir. Hamurları daha ince ve ince boyutta seyrek kuvars katkılıdır. Neolitik ve Erken Kalkolitik Çağ yerleşimlerinin yoğun buluntu grubunu oluşturan sapan çift konili sapan taneleri Hacılar III-IIA'da (Mellaart, 1970, s. 26-XXVI/a), Bademağacı'nda (EN II) (Duru ve Umurtak 2019, Levha 125/9-10), Höyücek’te (TD) (Duru ve Umurtak 2005, Levha/Plate 133/1-4), Ekşi Höyük’te (MÖ 6200-6000) (Dedeoğlu vd., 2017, s. 394, Resim 4), Ulucak'ta (Va-IVb) (Korfmann, Dedeoğlu ve Erdalkıran 2007; Çilingiroğlu ve ark., 2012, Fig.11, Fig. 19) ve Yeşilova'da (III.1-2) (Derin ve ark., 2009, Fig.31) da ele geçmiştir.

\section{Sürtmetaş Buluntular}

Düzkışla Höyük yüzey buluntuları arasında önemli başka bir buluntu grubu taş buluntular. $\mathrm{Bu}$ buluntu grubunun içinde yassı baltalar, keskiler, çeşitli tiplerde havan elleri, ögütme ve ezgi taşları ile mermer kap parçaları yer almaktadır. Bazı örnekler bölgenin yerel taşından şekillendirilirmiştir. Banaz'da, kimyasal tortul kayaç formasyonunun görüldügüü küçük bölgenin içinde Düzkışla Höyüğü'nün bulunduğu alan da yer alır (Atasoy, 2017, s. 22, Harita 7).

Sürtmetaş buluntular arasında ele geçen bir adet dikdörtgen formlu (Resim 7/7) ve iki adet trapez formlu (Resim 7/8-9) yassı balta bazalttan yapılmıştır. Dikdörtgen formlu ve trapez formlulardan birisi keskin uçludur. Ortalama 7-8 cm uzunluğunda, $5 \mathrm{~cm}$ genişliğinde olan baltaların kullanım alanları arasında küçük ahşap işleri ve et parçalama işleri sayılır. Uç kısımlarında kullanımdan kaynaklanan aşınma ve kırıklar dikkati çeker. Yassı baltaların hammaddesi olan bazalt, Düzkışla Höyük'ün kuzeydoğusundaki Karaköse Köyü ve güneybatısındaki Karanlıcak Tepe civarında görülen bir kayaç türüdür (Atasoy, 2017, s. 24, Harita 8). Yassı baltalara ek olarak, bir adet serpantinden yapılmış keski ele geçmiştir. 
Kare kesitli, üst kısmı yuvarlatılmış ve ucu keskin olan minyatür keski iyi perdahlanmıştır (Resim 7/10). Bu tip minyatür keskiler bir kemik veya boynuz sapa geçirilerek kullanılırdı (Mellaart, 1970 s. 452/1; Duru ve Umurtak 2005, Levha/Plate 141). Benzer yass1 taş baltalara ve keskilere birçok Neolitik ve Erken Kalkolitik Çağ buluntusu veren yerleşimde rastlamaktayız. Diğer buluntularla koşut bölgelere bakıldığında, trapez formlu yassı baltalar ve keskiler Hacılar II'de (Mellaart, 1970, s. 451; Derin, 2012, Fig.14), Kuruçay'da hem Neolitik (Duru, 1994, Levha 223/8-10) hem de Erken Kalkolitik (Duru, 1994, Levha 224/13) tabakalarda, Höyücek'te Tapınaklar Dönemi'nde5 , Bademağacı (Duru ve Umurtak 2019, Levha/Plate 131/1-10) EN II'de, Batı Anadolu'da Yeşilova'da Neolitik III.1'de (Derin ve ark., 2009, Fig.21) ve Ulucak IVb'de (Çilingiroğlu ve ark., 2012, Fig. 16) görülmektedir.

Teknolojisinden ziyade daha çok temel yaşam biçimi ve üretim ile ilgili bilgiler veren öğ̈̈tme ve ezme taşlarıyla birlikte havanelleri taş buluntular arasında diğer bir gruptur (Resim 7/11-18). Hayvancılık için uygun alanların bulunduğu Düzkışla ve çevresi ayrıca tarım için de yeterli arazilere ve imkanlara sahiptir. Öğütme ve ezme taşları ile havan elleri, tarıma dayalı yaşam biçiminin önemli göstergelerindendir. Havan elleri içinde bazalttan sürterek yapılan örneklerin yanı sıra üst yuvarlak bölümünün kabuklu bırakıldığı ve yontularak sivriltilen havan elleri ele geçmiştir (Resim 7/12). Bunların daha yaygın olarak görüldüğü ve bir işlik veya endüstriyel bir alan olarak yorumladığımız Ada Höyük’te çok çeşitli tipleri görülmektedir. Çok oluklu havanlarla birlikte ele geçen bu tipte havan elleri, cevher ayıklama işlemlerinde kullanılan aletleri anımsatsa da şimdilik bu konudaki verilerden yoksunuz. Söz konusu tipte havan ellerinin paralellerini farklı bölgelerdeki yerleşimlerde görmemekteyiz. Gözenekli andezitten yapılan, sürtülerek şekillendirilen havanellerinin benzerlerine Höyücek Tapınaklar Dönemi (Duru ve Umurtak 2005, Levha 147/5-7) ve Kuruçay Erken Kalkolitik Çağ tabakalarında (Duru, 1994, Levha 226/5-6) rastlamaktayız.

Taş buluntular içinde değerlendireceğimiz son buluntu grubu ise mermerden yapılmış kap parçaları ve havandır (?) (Resim 7/19-24). Çanak Çömleksiz Neolitik Çağ'da başlayan mermer kaplar, çanak çömleğin ortaya çıkışından sonra dönem içinde azalarak kaybolur. Beyaz mermer ve gri damarlı mermerden yapılmış nesneler bir çanak ağız parçası, bir gövde, bir minyatür kâse veya kupa (?), bir havan veya küresel kabın taslağı ile bir adet hayvan başlı kap parçası (sap?). Hayvan başlı kap parçası ve küresel gövdeli kabın taslağının dış yüzeyinde pürüzsüz bir düzeltme yoktur. Sadece kap taslağının iç kısmı düzeltilmiştir. Diğer buluntuların iç ve dış yüzeyleri pürüzsüzdür. Beyaz mermerden yapılmış dikey ağız kenarlı çanağın (Resim 7/2) benzerleri, Hacılar IIB buluntuları arasında görülür (Mellaart, 1970, s. 150, 163/5, 8). Kıyaslama için kullanabileceğimiz diğer örnek ise hayvan biçimli parçalardır (Resim 7/1). Birleşim yerinde korunan küçük bir profil izinden dolayı bir kabın parçası olduğu

5 Duru ve Umurtak 2005: Trapez formlu baltalar Levha/Plate 145/3-5; Keskiler Kutsal Alanlar Dönemi Levha/ Plate 145/7-10 
düşünülmektedir. Kulak, burun ve boynun belirgin verildiği bu objede göz ve ağız gibi detaylar belli değildir. Bu tip mermer kap parçalarının benzerlerini Höyücek Tapınaklar Dönemi'nden ele geçen kepçelerde görüyoruz (Duru ve Umurtak 2005, Levha/Plate 153/3). Gri damarlı mermerden yapılan kupa veya derin minyatür kabın profil olarak değilse de benzerleri Hacılar IIA'da karşımıza çıkmaktadır (Mellaart, 1970, s. 150, 163/2). Kuruçay Höyük'te de Neolitik ve Erken Kalkolitik Çağ'a tarihlenen az sayıda mermer kap parçası ele geçmiştir (Duru, 1994, Levha 222/6-8). Bununla birlikte, Kıyı Ege Neolitiğinin önemli yerleşimlerinden biri olan Yeşilova Höyük Neolitik III. 6-8'de de mermer kaplar görülmektedir (Derin ve ark., 2009, s.18, Fig.22; Derin, 2012, s. 180, Fig.11). Ege Gübre ve Ulucak gibi diğer Kiyı Ege Neolitik Çă̆ yerleşimlerinde mermer kaplarla ilgili bir veri yoktur.

\section{Yontmataş Buluntular}

Düzkışla Höyüğü'nden ele geçen taş buluntular arasında son bahsedeceğimiz grup yontmataşlardır ${ }^{6}$. Toplam 150 adet yontmataş buluntu yüzeyden toplanmıştır. Bunların 86 tanesi obsidyenden, 52 tanesi çakmaktaşından ve 12 tanesi kalsedondan üretilmiştir. Obsidyen buluntular, makroskobik gözlemlerimize dayanarak ağırlıklı olarak Orta Anadolu, az sayıda da Melos kökenli özellikler sergilemektedir. Buluntu topluluğu 97 adet dilgi, 33 adet yonga, 7 adet çekirdek, 1 adet yongalama ürünü ve 12 adet döküntüden oluşmaktadır. Alet olarak düzeltili veya kullanım sonucu oluşmuş aşınma izine sahip yonga ve dilgilerin yanı sıra az sayıda dişlemeli ve çentikli aletler bulunmaktadır. Kaynağı uzak olan obsidiyenin yerleşimde çakmaktaşından fazla olması tamamen yüzey araştırma sırasındaki toplama stratejisi ve seçicilik ile alakalıdır. Buradaki kantitatif değerlendirmelerden şimdilik aksi bir sonuç çıkartamayız.

Yerleşim alanında yontmataş aletler ile birlikte az sayıda da olsa çekirdekler ele geçmiştir. Bu çekirdekler arasında tipolojik olarak mermi biçimli olanların bulunması dikkat çekmektedir. Çekirdeklerde genellikle tek kutuplu yongalama yapılmıştır. Bunun yanı sıra oldukça az sayıda çakmaktaşı yontmataş öğesi üzerinde kabuk kalıntısı gözlenmiştir. Bu durum, en azından çakmaktaşların yerleşime kimi zaman yumrular halinde taşındığını ve yongalamanın burada gerçekleştirildiğine yönelik kanıt oluşturmaktadır.

\section{Genel Değerlendirme ve Sonuç}

Uşak Protohistorik Dönem Yüzey Araştırmaları Projesi (UPDAP) 2019 yılı çalışmalarıyla tespit edilen Düzkışla Höyük zengin buluntu topluluğuyla bölgenin prehistoryasına dair önemli veriler sağlamıştır. Neolitik yaşam biçiminin Anadolu’daki dağılımını ve yayılımını anlamak açısından önem taşıyan Düzkışla buluntuları, özellikle şimdiye kadar çok kısıtlı Neolitik araştırmalara sahne olmuş Uşak’ta yer alması bakımından ön plana çıkar. Nitekim yakın

6 Düzkışla yontmataş buluntuların değerlendirileceği bir yayın Betül Fındık ve Berkan Erdem tarafından hazırlanmaktadır. 
zamana kadar Uşak ve çevresi Neolitik Dönemle ilişkili yayınlarda ve haritalarda bir boşluk olarak kalmıştı. Elbette ki yüzey araştırmalarıyla elde edilen söz konusu veriler bu sorunu kökten çözmeye yetmez. Yüzey araştırmasına dayanan Düzkışla verileri ileride yapılacak olan daha kapsamlı çalışmalara katkı sağlaması amacıyla bu çalışmada değerlendirildi.

Banaz ve Uşak Ovası'nın bir kısmında gerçekleştirilen araştırmalarda Neolitik veya Kalkolitik Çağ’a işaret eden yerleşimler bulunmamıştır. Bu durum ovalardaki alüvyon dolgunun yükselmesiyle açıklanabileceği gibi tarımla ilişkilendirilen toplulukların ovalardan ziyade vadi içine uzanan sırt veya tepe üzerinde yerleşmesi, hammadde kaynaklarına veya diğer besin kaynaklarına yakın olma çabasıyla açıklanabilir. Gerek çanak çömlek yapımı için kullanılan kil gerekse de taş aletlerin yapımında kullanılan hammaddenin bölge kökenli olduğu, makroskopik gözlemler ve bölgede gerçekleştirilen kaynak analizlerinden anlaşılmaktadır (Atasoy, 2017).

Neolitik yaşam biçiminin yayılımı çerçevesinde Düzkışla Höyük önemli bir güzergâh üzerinde yer almaktadır. Yapılan araştırma sonuçları, şimdilik Göller Yöresi ile Neolitik ve Kalkolitik Çağ kültürel etkileşiminin iki farklı güzergâh üzerinden yaşandığını göstermektedir. Bunlardan ilki Burdur Gölü'nün kuzeydoğusundan Dinar, Sandıklı, Hocalar'a giden güzergahdır. Güzergâh üzerinde yer alan Üçin, Bektaş Üyük Tepe, Devlethan ve Asarın Tepe yerleşimlerinden elde edilen buluntular bu görüşü destekler niteliktedir. Diğer bir güzergahın ise Çivril Ovası üzerinden kuzeye doğru ilerlediği düşünülebilir. Bu güzergâh üzerinde de anahtar yerleşim olarak Ekşi Höyük gösterilebilir. Kazıcısının ifadesiyle de yerleşimden elde edilen buluntular Göller Yöresi karakterini yansıtmaktadır (Dedeoğlu ve ark., 2017, s. 394). İç Batı Anadolu'da tek yönlü bir kültür etkileşimini düşünmek yanlıştır. Batı Anadolu'da gelişen Neolitik ve Erken Kalkolitik Çağ kültür etkileri de İçbatı Anadolu'yu etkilemiştir. Bu da hem Ekşi Höyük kazı buluntuları hem de Düzkışla'da görülen çanak çömlek buluntular ile desteklenebilir.

Söz konusu kültürel etkileşimin yaklaşık hangi tarihler arasına yayıldığı, özellikle MÖ 7. binyılın ikinci yarısında Anadolu'nun batı bölümünün neredeyse tamamında görülen, Neolitik yaşam biçiminin kendine özgü materyal kültür öğeleriyle anlaşılmaya çalışılmıştır. Yapılan analojik çalışma ile de Düzkışla' daki yerleşimin ne zaman başlayıp ne zaman sona erdiğiyle ilgili çıkarımlar yapılmıştır.

Çalışmada ele alınan buluntu gruplarının sadece çanak çömlekten ibaret olmayıp dönemin karakteristiğini yansıtan figürin, mermer kaplar gibi sürtmetaş buluntuları da içermesi göreli tarihlemede birbirini desteklemiştir. Kıyaslamalı olarak değerlendirilen çanak çömlek buluntularının en erken paralelleri, Bademağacı EN I/6 (MÖ 7100-6500) ile Keçiçayır'ndan (MÖ 6600-6300) gelmektedir. Düzkışla Höyük’teki dikine ip delikli tutamaklar, hayvan biçimli tutamaklar, sepet kulplar ve pervaz ağızlı çömleklerin yakın paralellerinin ulaştığı bu erken tarihler 
diğer buluntu topluluklarıyla desteklenememiştir. Az sayıda olan bu çanak çömleklerin yanı sıra kahverengi ve kırmızı astarlı, 'S' profilli çanaklarla temsil edilen çanak çömlek grubu, Hacılar IX-VI (MÖ 6410-6250), Kuruçay 13-11 (MÖ 6230-5800), Höyücek TD (MÖ 6280-6080), Bademağacı EN II (MÖ 6400-6100), Ekşi Höyük (MÖ 6400-6000), Ulucak IV (MÖ 6040-5740) ve Yeşilova III 3.5'te (MÖ 6200-6060) görülmektedir. Fikirtepe Kültürü'nü temsil eden bezemeler veya ayaklı kutular ile Batı Anadolu'da MÖ 6000'dan sonra görülen baskı bezekli (impresso) bezemenin örnekleri Düzkışla Höyük’te görülmemektedir. MÖ 6000'den sonra çanak çömlek kültüründe baskın bir rol oynayan boyalı örnekler Erken Kalkolitik Çağın temsilcisi olmuşlardır.

Çanak çömlek verileriyle koşut olarak steatopik figürinler Çatalhöyük II, Hacılar VI, Kuruçay 11 ve Bademağacı EN II'de karşımıza çıkmaktadır. Ancak konik biçimli antropomorfik figürinin Ain-Gazal, Tell Aswad, Tell Ramad, Basta ve el-Şifiye'deki benzerleri Geç PPNB'ye tarihlenmektedir (Mahasneh ve Bienert, 1999: s. 116). Şimdilik hakkında çok az bilgi sahibi olduğumuz bu tekil buluntu göreli tarihleme dışında tutulmuştur. Bununla birlikte ele geçen yassı baltalar (Hacılar II, Kuruçay 13-7, Höyücek TD, Bademağacı EN II, Yeşilova'da Neolitik III.1, Ulucak IVb), mermer kap parçaları (Hacılar IIB-A, Yeşilova Neolitik III 6-8) ve çift konili sapan tanelerinin paralelleri (Ekşi Höyük MÖ 6200-6000, Ulucak Va-IVb, Yeşilova Neolitik III. 1-2, Bademağacı EN II, Höyücek TD) diğer buluntularla örtüşen bir kronolojik dizin içine yerleşmektedir. Yerleşimden ele geçen yontmataş buluntular üzerinde gerçekleştirilen ilk tekno-tipolojik gözlemler sonucu, söz konusu buluntuların ağırlıklı olarak Neolitik ve Erken Kalkolitik Çağ'ın karakteristiğini yansıtır nitelikte dilgi ağırlıklı olduğunu belirtmemiz mümkündür. Yontmataşlar içinde Kapadokya kökenli obsidyenlerin yoğun olması İç Batı Anadolu'nun takas ağlarına olan etkin katılımını gösterir. Orta Anadolu obsidyenlerinin az sayıda da olsa, Kıyı Ege'ye kadar uzandığı son yıllardaki çalışmalarla ortaya çıkmıştır (Milić, 2016; Çilingiroğlu ve ark., 2018, s. 76-77). Olasılıkla Uşak, Kıyı Ege ve Kapadokya arasındaki coğrafi konumuyla Neolitik ve Erken Kalkolitik takas ağlarında önemli aktarım bölgelerinden birini oluşturuyordu.

Yukarıda sunulan veriler 1şığında olasılıkla MÖ 6300/6200-5800/5700 tarihleri arasına yerleştirebileceğimiz Düzkışla buluntuları, Uşak çevresinin kapsamlı değerlendirilen ilk Geç Neolitik- Erken Kalkolitik Dönem höyüğü olarak, erken çiftçi yaşam biçiminin yerel karakterini ve bölgeler arası kültürel ilişkilerin boyutunu göstermesi açısından önemlidir.

\footnotetext{
Hakem Değerlendirmesi: Dış bağımsız.

Çıkar Çatışması: Yazar çıkar çatışması bildirmemiştir.

Finansal Destek: Yazar bu çalışma için finansal destek almadığını beyan etmiştir.

Peer-review: Externally peer-reviewed.

Conflict of Interest: The author has no conflict of interest to declare.

Grant Support: The author declared that this study has received no financial support.
} 


\section{Kaynakça/References}

Abay, E. (2011). Preliminary Report on the Survey Project of Çivril, Baklan, Çal Plains in the Upper Meander Basin. Southwest Anatolia, Ancient Near Eastern Studies, 48, 1-87.

Atasoy, A. (2017). Uşak Atlası. Kayseri.

Baird, D., Fairbairn, A., Martin, L. \& Middleton, C. (2012). The Boncuklu Project. The Origins of Sedentism, Cultivation and herding in Central Anatolia. M. Özdoğan, N. Başgelen, P. Kuniholm (Ed.), The Neolithic in Turkey: New Excavations \&New Research. Vol. 4, Western Turkey içinde (s. 219-244). İstanbul: Arkeoloji ve Sanat Yayınları.

Bilgi, Ö. (1980). Yeni Bulunmuş Eserlerin Iş̧ı̆ı Altında Anadolu'da Bronz Çağı Öncesi İnsan Figürleri Hakkında Yeni Gözlemler. Belleten XLIV, 173, 1-24.

Bilgi, O. (2012). Anadolu'da İnsan Görüntüleri: Klasik Çağ Öncesi. İstanbul: Arkeoloji ve Sanat Yayınları.

Çilingiroğlu, A., Çevik, Ö. \& Çilingiroğlu, Ç. (2012). Ulucak Höyük. Towards Understanding the Early Farming Communities of Middle West Anatolia: Contribution of Ulucak, M. Özdoğan, N. Başgelen, P. Kuniholm (Ed.), The Neolithic in Turkey: New Excavations \&New Research. Vol. 4, Western Turkey içinde (s. 139-175). İstanbul: Arkeoloji ve Sanat Yayınları.

Çilingiroğlu, Ç. (2005). The Concept of "Neolithic package": Consediring its Meaning and Applicability. Documenta Praehistorica XXXII, 1-13.

Çilingiroğlu, Ç. (2012). The Neolithic Pottery of Ulucak in Aegean Turkey. Organization of production, interregional comparisons and relative chronology. BAR International Series 2426.

Çilingiroğlu, Ç. (2017). The Aegean Before and After 7000 BC Dispersal: Defining Patterning and Variability. Neo-Lithics 1/16, 32-41.

Çilingiroğlu, Ç., Uhri, A., Dinçer, B., Baykara, İ., Çakırlar, C., Turan, D., Dinçerler, E. ve Sezgin, E. (2018). Kömür Burnu: İzmir-Karaburun'da Çok Dönemli Bir Prehistorik Buluntu Alanı. Arkeoloji Dergisi, XXIII, 65-90.

Dedeoğlu, F. (2014). Yukarı Menderes Havzası Neolitik ve Erken Kalkolitik Çağ Yerleşimlerinin Materyal Kültür ve İskân Düzeni Bağlamında Değerlendirilmesi. Pamukkale Üniversitesi Sosyal Bilimler Enstitüsü Dergisi, 18, 33-56.

Dedeoğlu, F. \& Ozan, A. (2016). What Happened in Inland Southwestern Anatolia before 5500 BC?: A Review of the Archaeological Evidence from the Selcen-Örenaras1 Settlement. OLBA, 24, 1-30

Dedeoğlu, F., Baysal, H.H., Ozan, A., Konakçı, E. ve Temür, B. (2017). Ekşi Höyük 2015 Y11ı Kazı Çalışmaları. Kazı Sonuçları Toplantısı 38 (2). İçinde (s. 389-402), Ankara: İsmail Aygül Ofset Matbaacılık.

Dedeoğlu, F., Baysal, H.H., Ozan, A., Konakçı, E. ve Temür, B. (2018). Ekşi Höyük 2016 Yılı Kazı Çalışmaları. Kazı Sonuçları Toplantısı, 39 (1). İçinde (s. 553-568), Bursa: Bursa Büyükşsehir Belediyesi Matbaa Tesisleri.

Deniz, M., Ayaydın, A. ve Kahraman, A. (2014). Banaz'da Ulaşım Faaliyetleri. M. Ertürk- A. Uzun-Şevki Danacıŏlu (Ed.). Coğrafyacılar Derneği Uluslararası Kongresi Bildiriler Kitabı içinde (s. 400-409). Balıkesir.

Derin, Z. (2012). Yeşilova Höyük, M. Özdoğan, N. Başgelen, P. Kuniholm (Ed.), The Neolithic in Turkey: New Excavations \&New Research. Vol. 4, Western Turkey içinde (s. 177-195). İstanbul: Arkeoloji ve Sanat Yayınları. 
İ̧̧ Batı Anadolu Neolitik-Kalkolitiğine Dair Yeni Bulgular: Düzkışla Höyük, Uşak

Derin, Z., Ay, F. ve Caymaz, T. (2009). İzmir'in Prehistorik Yerleşimi-Yeşilova Höyüğü 2005-2006 y1lı Çalı̧̧maları. Arkeoloji Dergisi XIII (2009/1), 7-58.

Duru, R. (1994). Kuruçay I. 1978-1988 Kazılarının Sonuçları Neolitik ve Erken Kalkolitik Çağ Yerleşmeleri. Ankara: Türk Tarih Kurumu.

Duru, R. (1996). Bademağacı Höyüğ̈̈ (Kızılkaya) Kazıları 1993 Yılı Çalışma Raporu. Belleten LX -229, 783-800 (14 Levha ile birlikte).

Duru, R. (2007). Göller Bölgesi Neolitiği. Hacılar-Kuruçay Höyüğü-Höyücek-Bademağacı Höyüğü. M. Özdoğan-N. Başgelen (Ed.). Anadolu'da Uygarlı̆̆ın Doğuşu ve Avrupa 'ya Yayılımı, Türkiye'de Neolitik Dönem, yeni kazılar, yeni bulgular içinde (s. 331-360). İstanbul: Arkeoloji ve Sanat Yayınları.

Duru, R. (2012). The Neolithic of the Lakes Region. Hacılar-Kuruçay Höyük-Höyücek-Bademağacı Höyük, M. Özdoğan, N. Başgelen, P. Kuniholm (Ed.), The Neolithic in Turkey: New Excavations \& New Research. Vol. 4, Western Turkey içinde (s. 1-65). İstanbul: Arkeoloji ve Sanat Yayınları.

Duru, R. ve Umurtak, G. (2005). Höyücek. 1989-1192 Yılları Arasında Yapılan Kazıların Sonuçları. Ankara: Türk Tarih Kurumu.

Duru, R. ve Umurtak, G. (2019). Bademağacı Höyüğ̈̈ Kazıları. Neolitik ve Erken Kalkolitik Çă̆ Yerleşmeleri I/Excavations at Bademă̆acı Höyük. The Neolithic and Early Chalcolithic Settlements. İstanbul: Ege Yayınları.

Efe, T. (1995). “İçbatı Anadolu' da İki Neolitik Yerleşme: Fındık Kayabaşı ve Akmakça. A. Erkanal ve diğerleri (Ed.). I. Metin Akyurt ve Bahattin Devam Anı Kitabı. Eski Yakın Doğu kültürleri Üzerine Incelemeler içinde (s. 105-114). İstanbul: Arkeoloji ve Sanat Yayınları.

Efe, T., Türkteki, M., Sarı, D. ve Fidan, E. (2015). Bilecik ili 2013 Yı1ı Yüzey Araştırması. Araştırma Sonuçları Toplantısı 32 (1), içinde (s. 495-504). Ankara.

Fidan, E. ve Küçükaydın, H. (2019-2020) Fikirtepe Kültürü'nün Öncesi: Bilecik Bahçelievler. Türk Eskiçağ Bilimleri Enstitüsü, Haberler 45, 96.

Galik, A. \& Horejs, B. (2011). Çukuriçi Höyük-Various Aspects of its Earliest Settlement Phase. Raiko Krauß (Ed.), Beginnings-New Research in the Appearance of the Neolithic between Northwest Anatolia and the Carpathian Basin. Papers of the International Workshop $8^{\text {th }} 9^{\text {th }}$ April 2009, İstanbul içinde (s. 83-94). Rahden/Westf.: Leidorf.

Hodder, I. (2012). Renewed Work at Çatalhöyük, M. Özdoğan, N. Başgelen, P. Kuniholm (Ed.), The Neolithic in Turkey: New Excavations \& New Research. Vol. 3, Central Turkey içinde (s. 245-277). İstanbul: Arkeoloji ve Sanat Yayınları.

Horejs, B. (2012). Çukuriçi Höyük. A Neolithic and Bronze Age Settlement in the Region of Ephesos. M. Özdoğan, N. Başgelen, P. Kuniholm (Ed.), The Neolithic in Turkey: New Excavations \& New Research. Vol. 4, Western Turkey içinde (s. 117-131). İstanbul: Arkeoloji ve Sanat Yayınları.

Horejs, B. (2017). Çukuriçi Höyük 1. Anatolia and the Aegean from the $7^{\text {th }}$ to the $3^{\text {rd }}$ Millennium BC. Vienna: Austrian Academy of Science Press.

Horejs, B. \& Milić, B.-Ostmann, F.-Thanheiser, U.-Weninger, B.-Galik, A. (2015). The Aegean in the Early 7th Millennium BC: Maritime Networks and Colonization. Journal of World Prehistory, 28, 289-330.

Kara, H. (2010). Banaz İlçesinin Coğrafyası, Konya.

Koçak, Ö. (2015). Afyonkarahisar İli ve İlçeleri ile Uşak İli Sivası İlçesi 2013 Yılı Yüzey Araştırmaları. Araştırma Sonuçları Toplantısı 32 (1) içinde (s. 355-374). Gaziantep. 
Koçak, Ö. ve Bilgin, M. (2010). Afyonkarahisar'da İki Önemli Son Neolitik/İlk Kalkolitik Dönem Yerleşme Yeri: Eyice ve Pani Höyük. TÜBA-AR, 13, 23-38.

Koçak, Ö. ve Bilgin, M. (2012). İçbatı Anadolu Bölgesinde Geç Neolitik ve Erken Kalkolitik Çağa Ait Yeni Yerleşmeler. Höyük, 5, 1-10.

Koçak, Ö. ve Bilgin, M. (2013). Afyonkarahisar Üçin Buluntuları Işı̆̆ında Batı Anadolu Prehistoryası Üzerine Yeni Gözlemler. ADALYA, XVI, 31-48.

Korfmann, M.O., Dedeoğlu, F. ve Erdalkıran, M. (2007). Ulucak Höyük Neolitik Dönem Sapan Taneleri, G. Umurtak-Ş. Dönmez- A. Yurtsever (Ed.). Refik Duru'ya Armağan içinde (s. 41-59). İstanbul: Ege Yayınları.

Mahasneh, H. M. \& Bienert, H.D. (1999). Anthropomorphic Figurines from the Early Neolithic Site of eşŞifiye (Jordan). Zeitschrift de Deutschen Palästina-Vereins, (1953-)115/2, 109-126.

Mellaart, J. (1954). Preliminary report on a survey of pre-classical remains in southern Turkey. Anatolian Studies, 4, 175-239.

Mellaart, J. (1961). Early Cultures of the South Anatolian Plateau. Anatolian Studies, 11, 159-184.

Mellaart, J. (1970). Excavations at Hacular. Edinburgh: Edinburgh University Press.

Milić, M. (2016). A question of scale? Connecting communities through obsidian exchange in the Neolithic Aegean, Anatolia and Balkans, B. Molloy (Ed.), Of Odysseys and Oddities: Scales and modes of interaction between prehistoric Aegean societies and their neighbours, Sheffield Studies in Aegean Prehistory, içinde (s. 97-123). Oxford.

Obladen-Kauder, J. (1996). Die Kleinfunde aus Ton, Knochen und Metall, Demircihüyük IV: Die Kleinfunde. B., Mainz am Rhein.

Oy, H. (2017). Uşak İli’nde Bulunan Neolitik ve Kalkolitik Bir Yerleşim: Altıntaş Höyük. Süleyman Demirel Üniversitesi Sosyal Bilimler Enstitüsü Dergisi, 28, 337-358.

Oy, H. (2019). Banaz'da İki Son Neolitik/İlk Kalkolitik Çă̆ Yerleşimi: Ada Höyük ve Mercimeklik, SDÜ Fen-Edebiyat Fakültesi Sosyal Bilimler Dergisi, 47, 16-41.

Özbaşaran, M. (2013). Orta Anadolu'nun Neolitikleşme Sürecinde AŞIKLI. Colloquium Anatolicum, XII, 1-14.

Özbaşaran, M. ve Cutting, M. (2007). Orta Anadolu'da Neolitik Çağ, Ortaya Çıkışı ve Gelişimi, Vor 12000 Jahren in Anatolien- die ältesten Monumente der Menschheit / 12.000 Yll Önce Anadolu- İnsanlı̆ğn En Eski Anıtları. İçinde (s. 457-466). Karlsruhe: Badisches Landesmuseum.

Özdoğan, M. (2010). Westward Expansion of the Neolithic Way of Life: Sorting the Neolithic Package into Distinct Packages, P. Matthiae, F. Pinnock, L. Nigro, N. Marchetti (Ed.), Proceedings of the $6^{\text {th }}$ International Congress on the Archaeology of the Ancient Near East, May, 5th-10th 2008, "Sapienza"Università di Roma, Volume I, içinde (s. 883-897). Wiesbaden: Harrassowitz Verlag.

Özdoğan, M. (2011). Archaeological Evidence on the Westward Expansion of Farming Communities from Easternd Anatolia to the Aegean and the Balkans. Current Anthropology, 52/4, 415-S430.

Özdoğan, M. (2018). Marmara Denizi ve Neolitik Yaşam Biçiminin Anadolu'dan Avrupa'ya Aktarımi/ The Sea of Marmara and the Transmission of Neolithic Way of Life from Anatolia to Europe. TINA 10-Denizcilik Arkeolojisi Dergisi/Maritime Archaeology Periodical 10, 9-30.

Sağlamtimur, H. (2012). Neolithic Settlement of Ege Gübre. M. Özdoğan, N. Başgelen, P. Kuniholm (Ed.), The Neolithic in Turkey: New Excavations \&New Research. Vol. 4, Western Turkey içinde (s. 197-225). İstanbul: Arkeoloji ve Sanat Yayınları. 
Sarı, D. \& Akyol, Ş. (2019). The Early Neolithic pottery of Keçiçayiri and its place in the North-western Anatolian Neolithisation process, Documenta Praehistorica, XLVI, 138-156.

Seeher, J. (1987). Demircihüyük: Die Ergebnisse der Ausgrabungen 1975-1978 / Band III,1, Die Keramik 1: A. Die Neolitische und Chalkolitische Keramik; B. Die Frühbronzezeitliche Keramik der ãlteren Phasen (bis Phase G). Mainz am Rhein: Verlag Philipp von Zabern.

Sherratt, A. (2004). Fractal Farmers: Patterns of Neolithic Origin and Dispersal, J. Cherry- C. Scarre-S. Shenan (Ed.), Explaining the social change: studies in honour of Colin Renfrew, içinde (s. 53-63). McDonald Institute for Archaeological Research.

Söyler, Ş., Taşkıran, H., Czichon, R.M., Özçelik, K., Polat, S., Yılmaz, M. Ali, Erbil, E., Türker, M. ve Dağcı, D. (2018). Uşak Banaz Sürmecik Paleolitik Kazısı-2016, 39. Kazı Sonuçları Toplantısı, 2, (s. 281-391), Ankara.

Thissen, L. (2010). The Neolithic-Chalcolithic sequence in the SW Anatolian Lakes Region. Documenta Praehistorica, XXXVII, 269-282.

Yalçınlar, İ. (1955). Banaz Çayı Havzası ve Uşak Civarında Bünye ve Morfoloji Araştırmaları. Türk Coğrafya Dergisi, 13-14, 57-89.

Y1lmaz, M. Ali (2019). Uşak Protohistorik Dönem Yüzey Araştırmaları Projesi (UPDAP) 2017 Yı11 Sonuçları (İlk Sezon). Araştırma Sonuçları Toplantısı 36 (2), içinde (s. 425-452), Ankara.

Yılmaz, M. Ali, Czichon, R. M., Deniz, M., Dülger, H., Akın, S., Nacar, A., Söyler, A., Çelik, H. ve Yiğit, F. (2019). Uşak Protohistorik Dönem Yüzey Araştırması (UPDAP) 2018 Yı1ı Sonuçları, Araştırma Sonuçları Toplantısı 37 (2), içinde (s. 435-468), Ankara. 


\section{Katolog}

\section{Resim 2}

1. Env. No: BNZ.DZKŞL.054 Hamur Rengi: 7.5 YR-5/1 Gri İç Astar: 7.5 YR-6/4 A.kh. Dış Astar: 7.5YR-6/4 A.Kh. Mal tipi: OKH (MBW) Form tipi: PÇa1

2. Env. No: BNZ.DZKŞL.022 Hamur Rengi: 5YR-3/1 Ç.K.gri İç Astar: 5YR-5/4 Kr.kh. Diş Astar: 5YR5/4 Kr.Kh. Mal tipi: KMM (CMW) Form tipi: PÇa1

3. Env. No: BNZ.DZKŞL.027 Hamur Rengi: 7.5YR-3/1 Ç.K.Gri İç Astar: 7.5YR-6/4 A.Kh. Dış Astar: 7.5YR-6/4 A.Kh. Mal tipi: KPM (CPW) Form tipi: PÇa1

4. Env. No: BNZ.DZKŞL.046 Hamur Rengi: 2.5YR-4/6 Kr. İç Astar: 2.5YR-5/6 Kr. Dış Astar: 2.5YR5/6 Kr. Mal tipi: OKA (MRS) Form tipi: PÇa2

5. Env. No: BNZ.DZKŞL.055 Hamur Rengi: 5YR-5/4 Kr.kh. İç Astar: 7.5YR-4/3 Kh. Dış Astar: 7.5YR4/4 Kh. Mal tipi: OKAM (MBS) Form tipi: PÇa2

6. Env. No: BNZ.DZKŞL.030 Hamur Rengi: 7.5 YR-5/6 Gç.kh. İç Astar: 7.5YR-5/4 Kh. Dış Astar: 7.5YR-5/4 Kh. Mal tipi: OKH (MBW) Form tipi: PÇa2

7. Env. No: BNZ.DZKŞL.090 Hamur Rengi: 10YR-6/6 Kh.sr İç Astar: 10YR-4/6 K. sr.kh. Dış Astar: 10YR-7/3 Ç.Slk.kh. Mal tipi: OKRA (MCS) Form tipi: PÇa3

8. Env. No: BNZ.DZKŞL.108 Hamur Rengi: 7.5YR-5/6 Gç.kh. İç Astar: 7.5YR-6/4 A.kh. Dış Astar: 7.5YR-6/6 kr.sr Mal tipi: OKH (MBW) Form tipi: PÇa3

9. Env. No: BNZ.DZKŞL.091 Hamur Rengi: 7.5YR-7/2 Pmb.gri İç Astar: 5YR-5/6 Sr.kr. Dış Astar: 2.5YR-5/6 Kr. Mal tipi: OKA (MRS) Form tipi: PÇa3

10. Env. No: BNZ.DZKŞL.058 Hamur Rengi: 10 YR-4/1 K.gri. İç Astar: 10R-4/1 K.krmz.gri Dış Astar: 10R-3/6 K.Kr. Mal tipi: OKA (MRS) Form tipi: PÇa3

11. Env. No: BNZ.DZKŞL.069 Hamur Rengi: 7.5YR-5/3 Kh. İç Astar: 7.5 YR-5/4 Kh. Dış Astar: $7.5 Y R-$ 4/4 Kh. Mal tipi: OKAM (MBS) Form tipi: PÇa3

12. Env. No: BNZ.DZKŞL.065 Hamur Rengi: 7.5 YR-5/4 Kh. İç Astar: 7.5 YR-6/2 Pmb.gri Dış Astar: 7.5YR-5/6 Gç.Kh. Mal tipi: OKAM (MBS) Form tipi: PÇa3

13. Env. No: BNZ.DZKŞL.004 Hamur Rengi: 2.5 YR-4/6 Kr. İç Astar: 7.5YR-6/4 A.kh. Dış Astar: 7.5YR6/4 A.Kh. Mal tipi: OKH (MBW) Form tipi: PÇa3

14. Env. No: BNZ.DZKŞL.063 Hamur Rengi: 2.5YR-4/6 Kr. İç Astar: 7.5YR-6/4 A.kh. Dış Astar: 7.5YR6/4 A.Kh. Mal tipi: OKH (MBW) Form tipi: PÇa3

15. Env. No: BNZ.DZKŞL.070 Hamur Rengi: 7.5 YR-5/6 Gç.kh. İç Astar: 7.5YR-5/6 Gç.kh. Dış Astar: 7.5YR-5/6 Gç.Kh. Mal tipi: OKAM (MBS) Form tipi: PÇa3

16. Env. No: BNZ.DZKŞL.011 Hamur Rengi: $2.5 Y R-5 / 6$ Kr. İç Astar: 2.5YR-5/6 Kr. Dış Astar: 2.5YR5/6 Kr. Mal tipi: OKA (MRS) Form tipi: PÇa3

17. Env. No: BNZ.DZKŞL.068 Hamur Rengi: 2.5 YR-7/6 A.kr. İç Astar: $2.5 Y R-6 / 6$ A.kr. Dış Astar: 2.5YR-7/6 A.kr.Mal tipi: OKA (MRS) Form tipi: PÇa3

18. Env. No: BNZ.DZKŞL.093 Hamur Rengi: 7.5YR-5/4 Kh. İç Astar: 7.5YR-5/6 Gç.kh. Dış Astar: 7.5YR-5/6 Gç.Kh. Mal tipi: OKAM (MBS) Form tipi: PÇa3

19. Env. No: BNZ.DZKŞL.092 Hamur Rengi: 10YR-7/4 Ç.Slk.kh. İç Astar: 10YR-7/3 Ç.Slk.kh. Dış Astar: 7.5YR-6/6 Kr.sr. Mal tipi: OKRA (MCS) Form tipi: PÇa3 
20. Env. No: BNZ.DZKŞL.056 Hamur Rengi: 7.5YR-6/6 kr.sr. İç Astar: 7.5YR-6/4 A.kh. Dış Astar: 7.5YR-6/4 A.Kh. Mal tipi: OAK (MLB) Form tipi: PÇa3

21. Env. No: BNZ.DZKŞL.059 Hamur Rengi: 7.5YR-6/4 A.kh. İç Astar: 7.5YR-6/4 A.Kh. Dış Astar: 7.5YR-6/4 A.Kh. Mal tipi: OAK (MLB) Form tipi: PÇa3

22. Env. No: BNZ.DZKŞL.089 Hamur Rengi: 7.5YR-6/4 A.kh. İç Astar: 7.5YR-5/8 Gç.kh. Dış Astar: 7.5YR-6/4 A.Kh. Mal tipi: OAK (MLB) Form tipi: PÇa3

\section{Resim 3}

1. Env. No: BNZ.DZKŞL.094 Hamur Rengi: 7.5YR-5/8 Gç.kh. İç Astar: 7.5YR-5/6 Gç.kh. Dış Astar: 7.5YR-6/4 A.Kh. Mal tipi: OKRA (MCS) Form tipi: PÇa4

2. Env. No: BNZ.DZKŞL.095 Hamur Rengi: 7.5YR-5/4 Kh. İç Astar: 2.5YR-5/6 Kr. Dış Astar: 2.5YR5/6 Kr. Mal tipi: OKA (MRS) Form tipi: PÇa4

3. Env. No: BNZ.DZKŞL.087 Hamur Rengi: 2.5YR-5/4 Kr.kh. İç Astar: 7.5YR-6/4 A.kh. Dış Astar: 7.5YR-6/4 A.kh. Mal tipi: OAK (MLB) Form tipi: PÇa4

4. Env. No: BNZ.DZKŞL.006 Hamur Rengi: 7.5YR-6/4 A.kh. İç Astar: 7.5YR-6/4 A.kh. Dış Astar: 7.5YR-6/4 A.kh. Mal tipi: OAK (MLB) Form tipi: PÇa4

5. Env. No: BNZ.DZKŞL.067 Hamur Rengi: 10YR-7/3 Ç.Slk.kh. İç Astar: 10YR-7/3 Ç.Slk.kh. Dış Astar: 10YR-7/3 Ç.Slk.kh. Mal tipi: OAK (MLB) Form tipi: PÇa4

6. Env. No: BNZ.DZKŞL.088 Hamur Rengi: 10YR-5/3 Kh. İç Astar: 10YR-7/3 Ç.Slk.kh. Dış Astar: 10YR-7/3 Ç.Slk.kh. Mal tipi: OKRA (MCS) Form tipi: PÇa4

7. Env. No: BNZ.DZKŞL.072 Hamur Rengi: 7.5YR-5/4 Kh. İç Astar: 7.5YR-6/4 A.kh. Dış Astar: 7.5YR-6/3 A.kh. Mal tipi: OKRA (MCS) Form tipi: PÇa4

8. Env. No: BNZ.DZKŞL.007 Hamur Rengi: 7.5YR-4/3 Kh. İç Astar: 7.5YR-4/4 Kh. Dış Astar: 7.5YR4/4 Kh. Mal tipi: OKA (MRS) Form tipi: PÇö1

9. Env. No: BNZ.DZKŞL.003 Hamur Rengi: 10R-4/1 K.krmz.gri İç Astar: 10R-4/6 Kr. Dış Astar: 10R$4 / 6 \mathrm{Kr}$. Mal tipi: OKA (MRS) Form tipi: PÇö1

10. Env. No: BNZ.DZKŞL.049 Hamur Rengi: 7.5YR-3/1 Ç.K.Gri. İç Astar: 7.5 YR-5/6 Gç.Kh. Dış Astar: 7.5YR-5/6 Gç.kh. Mal tipi: OKAM (MBS) Form tipi: PÇö1

11. Env. No: BNZ.DZKŞL.040 Hamur Rengi: 2.5 YR-4/8 Kr. İç Astar: 10R-4/6 Kr. Diş Astar: 10R- 4/6 Kr. Mal tipi: OKA (MRS) Form tipi: PÇö2

12. Env. No: BNZ.DZKŞL.073 Hamur Rengi: 7.5YR-6/4 A.kh. İç Astar: 7.5YR-6/4 A.kh. Dış Astar: 7.5YR-6/4 A.kh. Mal tipi: OAK (MLB) Form tipi: PÇö3

13. Env. No: BNZ.DZKŞL.052 Hamur Rengi: 7.5YR-4/1 K.gri. İç Astar: 7.5YR-6/3 A.kh. Dış Astar: 10YR-5/1 Gri Mal tipi: OGK (MGB) Form tipi: PÇö3

14. Env. No: BNZ.DZKŞL.031 Hamur Rengi: 7.5YR-2.5/2 Ç.K.kh. İç Astar: 7.5YR-6/4 A.kh. Dış Astar: 7.5YR-6/4 A.Kh. Mal tipi: OKRA (MCS) Form tipi: PÇö3

15. Env. No: BNZ.DZKŞL.012 Hamur Rengi: 10YR-3/2 Ç.K.gri.kh. İç Astar: 2.5YR-3/1 K.Kr.Gri. Dış Astar: 10R- 4/4 Zyf. Kr. Mal tipi: OKA (MRS) Form tipi: PÇö3

16. Env. No: BNZ.DZKŞL.053 Hamur Rengi: 7.5YR-4/1 K.gri. İç Astar: 7.5YR-6/4 A.kh. Dış Astar: 7.5YR-6/4 A.kh. Mal tipi: OKAM (MBS) Form tipi: PÇö3 
17. Env. No: BNZ.DZKŞL.009 Hamur Rengi: 7.5YR-4/1 K.Gri. İç Astar: 7.5YR-5/4 Kh. Dış Astar: 7.5YR-5/2 Kh. Mal tipi: OGK (MGB) Form tipi: PÇö3

18. Env. No: BNZ.DZKŞL.020 Hamur Rengi: 2.5 YR-5/8 Kr. İç Astar: 2.5YR-5/8 Kr. Dış Astar: 2.5YR5/8 Kr. Mal tipi: KMM (CMW) Form tipi: PÇö3

19. Env. No: BNZ.DZKŞL.057 Hamur Rengi: 10YR-2/1 Syh. İç Astar: 10R-4/6 Kr. Dış Astar: 10R- 4/6 Kr. Mal tipi: OKA (MRS) Form tipi: PÇö3

20. Env. No: BNZ.DZKŞL.064 Hamur Rengi: 7.5YR-6/4 A.kh. İç Astar: 7.5YR-6/4 A.kh. Dış Astar: 7.5YR-5/6 Gç.Kh. Mal tipi: OKAM (MBS) Form tipi: PÇö3

21. Env. No: BNZ.DZKŞL.066 Hamur Rengi: 10R-4/4 Kr. İç Astar: 2.5YR-5/4 Kr.kh.. Dış Astar: 2.5YR5/4 Kr.kh. Mal tipi: OKA (MRS) Form tipi: PÇö3

22. Env. No: BNZ.DZKŞL.041 Hamur Rengi: 7.5YR-4/6 Gç.kh. İç Astar: 2.5YR-4/6 Kr. Dış Astar: 2.5YR-4/6 Kr. Mal tipi: OKA (MRS) Form tipi: PÇö3

\section{$\operatorname{Resim} 4$}

1. Env. No: BNZ.DZKŞL.071 Hamur Rengi: $2.5 Y R-4 / 4$ Kr.kh. İç Astar: 7.5YR-5/4 Kh. Diş Astar: 7.5YR-5/4 Kh. Mal tipi: OKH (MBW) Form tipi: PÇö4

2. Env. No: BNZ.DZKŞL.005 Hamur Rengi: 7.5YR-3/1 Ç.K.gri. İç Astar: 7.5YR-6/4 A.kh. Dış Astar: 7.5YR-6/4 A.kh. Mal tipi: KPM (CPW) Form tipi: PÇö4

3. Env. No: BNZ.DZKŞL.010 Hamur Rengi: 7.5YR-3/1 Ç.K.gri. İç Astar: 7.5YR-6/4 A.kh. Dış Astar: 7.5YR-6/4 A.kh. Mal tipi: KPM (CPW) Form tipi: PÇö4

4. Env. No: BNZ.DZKŞL.061 Hamur Rengi: 7.5YR-4/6 Gç.kh. İç Astar: 2.5YR-4/6 Kr. Dış Astar: 2.5YR-4/6 Kr. Mal tipi: OKA (MRS) Form tipi: PÇö4

5. Env. No: BNZ.DZKŞL.047 Hamur Rengi: 10YR-2/2 Ç.K.kh. İç Astar: 7.5YR-5/6 Gç.kh. Dış Astar: 7.5YR-5/6 Gç.kh. Mal tipi: KPM (CPW) Form tipi: PÇö4

6. Env. No: BNZ.DZKŞL.060 Hamur Rengi: 7.5YR-6/3 A.kh. İç Astar: 7.5YR-6/4 A.Kh. Dış Astar: 7.5YR-6/4 A.kh.. Mal tipi: OKH (MBW) Form tipi: PÇö4

7. Env. No: BNZ.DZKŞL.021 Hamur Rengi: 7.5 YR-5/1 Gri İç Astar: 7.5YR-5/4 Kh. Dış Astar: 7.5YR5/4 Kh. Mal tipi: KMM (CMW) Form tipi: PÇö4

8. Env. No: BNZ.DZKŞL.062 Hamur Rengi: 7.5YR-6/6 Kr.sr İç Astar: 7.5YR-6/4 A.kh. Dış Astar: 7.5YR-6/4 A.kh. Mal tipi: OAK (MLB) Form tipi: PÇö4

9. Env. No: BNZ.DZKŞL.045 Hamur Rengi: 7.5YR-6/8 Kr.sr İç Astar: 7.5YR-5/8 Gç.kh. Dış Astar: 7.5YR-5/4 Kh. Mal tipi: OKH (MBW) Form tipi: PÇö4

10. Env. No: BNZ.DZKŞL.048 Hamur Rengi: 7.5 YR-4/6 Gç.kh. İç Astar: 2.5YR-3/1 K.Kr.gri. Dış Astar: 7.5YR-5/4 Kh. Mal tipi: OKH (MBW) Form tipi: PÇö4

11. Env. No: BNZ.DZKŞL.043 Hamur Rengi: 10 R- 4/4 Kr. İç Astar: 2.5YR-5/4 Kr.kh. Dış Astar: 2.5YR4/5 Kr.kh. Mal tipi: OKA (MRS) Form tipi: PÇö4

12. Env. No: BNZ.DZKŞL.042 Hamur Rengi: 7.5 YR-5/6 Gç.kh. İç Astar: 7.5 YR-5/4 Kh. Dış Astar: 7.5YR-5/4 Kh. Mal tipi: OGK (MGB) Form tipi: PÇö4

13. Env. No: BNZ.DZKŞL.051 Hamur Rengi: 10YR-4/2 K.gri.kh. İç Astar: 10YR-6/1 Gri. Dış Astar: 10YR-6/1 Gri. Mal tipi: OGK (MGB) Form tipi: PÇö4 
14. Env. No: BNZ.DZKŞL.050 Hamur Rengi: 7.5YR-3/1 Ç.K.gri. İç Astar: 2.5YR-4/6 Kr. Dış Astar: 2.5YR-4/6 Kr. Mal tipi: KPM (CPW) Form tipi: PÇö4

15. Env. No: BNZ.DZKŞL.024 Hamur Rengi: 10 YR-3/1 Ç.K.gri. İç Astar: 10YR-4/2 K.gri.kh. Dış Astar: 10YR-4/2 K.gri.kh. Mal tipi: OGK (MGB) Form tipi: PÇö4

16. Env. No: BNZ.DZKŞL.008 Hamur Rengi: 10 YR-2/2 Ç.K.kh. İç Astar: 10YR-3/1 Ç.K.gri. Dış Astar: 10YR-3/1 Ç.K.gri. Mal tipi: OGK (MGB) Form tipi: PÇö5

17. Env. No: BNZ.DZKŞL.026 Hamur Rengi: 7.5YR-4/4 Kh. İç Astar: 7.5YR-5/4 Kh. Dış Astar: 7.5YR5/4 Kh. Mal tipi: KMM (CMW) Form tipi: PÇö5

18. Env. No: BNZ.DZKŞL.039 Hamur Rengi: 2.5 YR-5/1 Kr.gri İç Astar: 2.5YR-5/6 Kr. Dış Astar: 2.5YR-5/6 Kr. Mal tipi: KMM (CMW) Form tipi: PÇö5

19. Env. No: BNZ.DZKŞL.002 Hamur Rengi: $2.5 Y R-4 / 1$ K.Kr.gri. İç Astar: $2.5 Y R-5 / 6$ Kr. Dış Astar: 2.5YR-5/6 Kr. Mal tipi: KMM (CMW) Form tipi: PÇö5

20. Env. No: BNZ.DZKŞL.025 Hamur Rengi: 7.5YR-4/6 Gç.kh. İç Astar: 7.5YR-6/4 A.kh. Dış Astar: 7.5YR-6/4 A.kh. Mal tipi: KPM (CPW) Form tipi: PÇö5

21. Env. No: BNZ.DZKŞL.074 Hamur Rengi: 7.5 YR-4/2 Kh. İç Astar: 7.5 YR-4/4 Kh. Dış Astar: $7.5 Y R-$ 4/4 Kh. Mal tipi: OKH (MBW) Form tipi: PÇö6

22. Env. No: BNZ.DZKŞL.075 Hamur Rengi: 2.5 YR-5/6 Kr. İç Astar: 7.5YR-5/4 Kh. Dış Astar: 7.5YR5/4 Kh. Mal tipi: OKH (MBW) Form tipi: PÇö6

\section{Resim 5}

1. Env. No: BNZ.DZKŞL.085 Hamur Rengi: 7.5 YR-4/1 K.gri. İç Astar: 7.5 YR-5/3 Kh. Dış Astar: 7.5YR-5/4 Kh. Mal tipi: OKAM (MBS) Form tipi: PDip1

2. Env. No: BNZ.DZKŞL.083 Hamur Rengi: 7.5YR-4/1 K.gri. İç Astar: 7.5YR-5/4 Kh. Dış Astar: 7.5YR-5/4 Kh. Mal tipi: OKH (MBW) Form tipi: PDip1

3. Env. No: BNZ.DZKŞL.086 Hamur Rengi: 10YR-3/2 Ç.K.gri.kh. İç Astar: 10YR-4/2 K.gri.kh. Dış Astar: 10YR-4/2 K.gri.kh. Mal tipi: OGK (MGB) Form tipi: PDip1

4. Env. No: BNZ.DZKŞL.037 Hamur Rengi: 7.5YR-3/1 Ç.K.gri. İç Astar: 7.5YR-6/4 A.kh. Dış Astar: 7.5YR-6/4 A.kh. Mal tipi: OKAM (MBS) Form tipi: PDip1

5. Env. No: BNZ.DZKŞL.038 Hamur Rengi: 7.5YR-5/4 Kh. İç Astar: 5YR-6/4 A.Kr.kh. Dış Astar: 10YR-6/4 A.sr.kh. Mal tipi: OKH (MBW) Form tipi: PDip1

6. Env. No: BNZ.DZKŞL.084 Hamur Rengi: 7.5YR-4/1 K.gri. İç Astar: 7.5YR-6/4 A.kh. Dış Astar: 7.5YR-6/4 A.kh. Mal tipi: OAK (MLB) Form tipi: PDip1

7. Env. No: BNZ.DZKŞL.017 Hamur Rengi: 7.5YR-5/6 Gç.kh. İç Astar: 2.5YR-5/6 Kr. Dış Astar: 2.5YR-5/6 Kr. Mal tipi: OKH (MBW) Form tipi: PT1

8. Env. No: BNZ.DZKŞL.035 Hamur Rengi: 7.5YR-5/4 Kh. İç Astar: 7.5YR-6/3 A.kh. Dış Astar: 7.5YR-6/3 A.kh. Mal tipi: OKH (MBW) Form tipi: PT2

9. Env. No: BNZ.DZKŞL.077 Hamur Rengi: 7.5YR-3/2 K.kh. İç Astar: 7.5YR-6/1 Gri. Dış Astar: 7.5YR-6/2 Pmb.gri Mal tipi: OKH (MBW) Form tipi: PT2

10. Env. No: BNZ.DZKŞL.015 Hamur Rengi: 7.5 YR-4/1 K.Gri. İç Astar: 7.5YR-4/4 Kh. Dış Astar: 7.5YR-4/4 Kh. Mal tipi: OKAM (MBS) Form tipi: PKlp1 
11. Env. No: BNZ.DZKŞL.079 Hamur Rengi: 7.5YR-5/6 Gç.kh. İç Astar: 7.5YR-4/4 Kh. Dış Astar: 7.5YR-4/4 Kh. Mal tipi: OKAM (MBS) Form tipi: PKlp1

12. Env. No: BNZ.DZKŞL.076 Hamur Rengi: 7.5 YR-6/4 A.kh. İç Astar: 7.5YR-6/4 A.kh. Dış Astar: 7.5YR-6/4 A.kh. Mal tipi: OAK (MLW) Form tipi: PKlp3

\section{Resim 6}

1. Env. No: BNZ.DZKŞL.036 Hamur Rengi: 2.5 YR-2.5/1 Kr.si. İç Astar: 2.5 YR-5/4 Kr.kh. Dış Astar: 7.5YR-6/4 A.kh. Mal tipi: KPM (CPW) Form tipi: PKlp4

2. Env. No: BNZ.DZKŞL.082 Hamur Rengi: 7.5 YR-4/1 K.gri. İç Astar: 7.5YR-6/3 A.kh. Dış Astar: 7.5YR-4/4 Kh. Mal tipi: OKAM (MBS) Form tipi: PKlp4

3. Env. No: BNZ.DZKŞL.013 Hamur Rengi: 10YR-2/1 Syh. İç Astar: 2.5YR-5/8 Kr. Dış Astar: 2.5YR5/8 Kr. Mal tipi: KPM (CPW) Form tipi: PKlp4

4. Env. No: BNZ.DZKŞL.016 Hamur Rengi: 7.5YR-5/8 Gç.kh. İç Astar: 7.5YR-6/6 Kr.sr. Dış Astar: 7.5YR-6/6 Kr.sr. Mal tipi: OKAM (MBS) Form tipi: PKlp4

5. Env. No: BNZ.DZKŞL.078 Hamur Rengi: 2.5YR-3/1 K.Kr.gri. İç Astar: 2.5YR-5/3 Kr.kh. Dış Astar: 2.5YR-3/3 K.kr.kh. Mal tipi: OGK (MGB) Form tipi: PKlp5

6. Env. No: BNZ.DZKŞL.014 Hamur Rengi: 10YR-4/1 K.gri. İç Astar: 10YR-8/6 Sr. Dış Astar: 10YR8/6 Sr. Mal tipi: OKRA (MCS) Form tipi: PKlp5

7. Env. No: BNZ.DZKŞL.032 Hamur Rengi: 7.5YR-3/1 Ç.K.gri. İç Astar: 7.5YR-6/4 A.kh. Dış Astar: 7.5YR-6/4 A.kh. Mal tipi: KPM (CPW) Form tipi: PKlp5

8. Env. No: BNZ.DZKŞL.044 Hamur Rengi: 7.5YR-4/4 Kh. İç Astar: 7.5YR-5/4 Kh. Dış Astar: 7.5YR5/4 Kh. Mal tipi: OKH (MBW) Form tipi: Pkp1

9. Env. No: BNZ.DZKŞL.106 Hamur Rengi: 10YR-5/2 Gri.kh. İç Astar: 10YR-7/3 Ç.Slk.kh. Dış Astar: 10YR-7/3 Ç.Slk.kh. Mal tipi: OKRA (MCS) Form tipi: Gövde

10. Env. No: BNZ.DZKŞL.100 Hamur Rengi: 10YR-6/3 Slk.kh. İç Astar: 10YR-7/3 Ç.Slk.kh. Dış Astar: 10YR-7/3 Ç.Slk.kh. Mal tipi: OKRA (MCS) Form tipi: Gövde

11. Env. No: BNZ.DZKŞL.105 Hamur Rengi: 10 YR-6/3 Slk.kh. İç Astar: 10YR-7/3 Ç.Slk.kh. Dış Astar: 10YR-7/3 Ç.Slk.kh. Mal tipi: OKRA (MCS) Form tipi: Gövde

12. Env. No: BNZ.DZKŞL.099 Hamur Rengi: 10 YR-5/4 Sr.kh. İç Astar: 10YR-7/3 Ç.Slk.kh. Dış Astar: 10YR-7/3 Ç.Slk.kh. Mal tipi: OKRA (MCS) Form tipi: Gövde

13. Env. No: BNZ.DZKŞL.104 Hamur Rengi: 5YR-5/6 Sr.kr. İç Astar: 10YR-6/4 A.sr.kh. Dış Astar: 10YR-7/3 Ç.Slk.kh. Mal tipi: OKRA (MCS) Form tipi: Gövde

14. Env. No: BNZ.DZKŞL.097 Hamur Rengi: 5YR-5/6 Sr.kr. İç Astar: 7.5YR-6/4 A.kh. Dış Astar: 7.5YR-6/4 A.kh. Mal tipi: OAK (MLB) Form tipi: Gövde

15. Env. No: BNZ.DZKŞL.096 Hamur Rengi: 7.5 YR-5/6 Gç.kh. İç Astar: 7.5 YR-5/8 Gç.Kh. Dış Astar: 10YR-7/4 Ç.Slk.kh. Mal tipi: OKRA (MCS) Form tipi: Gövde

16. Env. No: BNZ.DZKŞL.116 Hamur Rengi: 7.5YR-5/6 Gç.kh. İç Astar: 7.5YR-6/3 A.kh. Dış Astar: 7.5YR-6/4 A.kh. Mal tipi: OAK (MLB) Form tipi: Gövde

17. Env. No: BNZ.DZKŞL.110 Hamur Rengi: 7.5YR-5/6 Gç.Kh. İç Astar: 7.5YR-6/6 kr.sr. Dış Astar: 7.5YR-6/4 A.kh. Mal tipi: OAK (MLB) Form tipi: Gövde 
18. Env. No: BNZ.DZKŞL.103 Hamur Rengi: 5YR-5/3 Kr.kh. İç Astar: 7.5YR-6/3 A.kh. Dış Astar: 7.5YR-6/3 A.kh. Mal tipi: OGK (MGB) Form tipi: Gövde

19. Env. No: BNZ.DZKŞL.111 Hamur Rengi: 7.5 YR-5/6 Gç.Kh.. İç Astar: 7.5YR-6/3 A.kh. Dış Astar: 7.5YR-6/4 A.Kh. Mal tipi: OAK (MLB) Form tipi: Gövde

20. Env. No: BNZ.DZKŞL.115 Hamur Rengi: 7.5 YR-5/6 Gç.Kh.. İç Astar: 7.5YR-6/3 A.kh. Dış Astar: 7.5YR-6/4 A.kh. Mal tipi: OAK (MLB) Form tipi: Gövde

21. Env. No: BNZ.DZKŞL.107 Hamur Rengi: 7.5YR-5/6 Gç.kh. İç Astar: 7.5YR-6/3 A.kh. Dış Astar: 7.5YR-6/4 A.kh. Mal tipi: OAK (MLB) Form tipi: Gövde

22. Env. No: BNZ.DZKŞL.098 Hamur Rengi: 7.5YR-5/4 Kh. İç Astar: 7.5YR-6/6 kr.sr. Dış Astar: 7.5YR6/4 A.Kh. Mal tipi: OAK (MLB) Form tipi: Gövde

23. Env. No: BNZ.DZKŞL.102 Hamur Rengi: 7.5YR-6/6 kr.sr. İç Astar: 7.5YR-6/4 A.kh. Dış Astar: 7.5YR-6/4 A.kh. Mal tipi: OAK (MLB) Form tipi: Gövde

24. Env. No: BNZ.DZKŞL.114 Hamur Rengi: 7.5YR-6/4 A.kh. İç Astar: 7.5YR-6/4 A.kh. Diş Astar: 7.5YR-6/4 A.kh. Mal tipi: OAK (MLB) Form tipi: Gövde

25. Env. No: BNZ.DZKŞL.109 Hamur Rengi: 7.5YR-4/6 Gç.kh. İç Astar: 7.5YR-6/3 A.kh. Dıı̧ Astar: 7.5YR-5/3 Kh. Mal tipi: OGK (MGB) Form tipi: Gövde

26. Env. No: BNZ.DZKŞL.112 Hamur Rengi: 7.5YR-4/1 K.Gri. İç Astar: 7.5YR-6/4 A.kh. Dış Astar: 7.5YR-6/4 A.kh. Mal tipi: OAK (MLB) Form tipi: Gövde

27. Env. No: BNZ.DZKŞL.113 Hamur Rengi: 7.5YR-5/6 Gç.kh. İç Astar: 7.5YR-6/4 A.kh. Dış Astar: 7.5YR-6/4 A.kh. Mal tipi: OAK (MLB) Form tipi: Gövde

28. Env. No: BNZ.DZKŞL.101 Hamur Rengi: 10YR-5/1 Gri İç Astar: 10YR-6/3 Slk.kh. Dış Astar: 10YR4/2 K.gri.kh. Mal tipi: OGK (MGB) Form tipi: Gövde

\section{Resim 7}

1. Env. No: UPDAP 2019/16 Buluntu tipi: Steatopik figürin parçası Malzemesi: Pişmiş toprak Yükseklik: $7.1 \mathrm{~cm}$ Genişlik: $4.5 \mathrm{~cm}$

2. Env. No: UPDAP 2019/1 Buluntu tipi: Konik figürin Malzemesi: Pişmiş toprak Yükseklik: $2,7 \mathrm{~cm}$ Genişlik: $2 \mathrm{~cm}$

3. Env. No: BNZ.DZKŞL.119 Buluntu tipi: Çift konili sapan tanesi Malzemesi: Pişmiş toprak Yükseklik: $3 \mathrm{~cm}$ Genişlik: $6 \mathrm{~cm}$

4. Env. No: BNZ.DZKŞL.120 Buluntu tipi: Çift konili sapan tanesi Malzemesi: Pişmiş toprak Yükseklik: $3 \mathrm{~cm}$ Genişlik: $5,8 \mathrm{~cm}$

5. Env. No: BNZ.DZKŞL.118 Buluntu tipi: yuvarlak formlu sapan tanesi Malzemesi: Pişmiş toprak Yükseklik: $4 \mathrm{~cm}$ Genişlik: $4 \mathrm{~cm}$

6. Env. No: BNZ.DZKŞL.121 Buluntu tipi: yuvarlak formlu sapan tanesi Malzemesi: Pişmiş toprak Yükseklik: $3,5 \mathrm{~cm}$ Genişlik: $3.7 \mathrm{~cm}$

7. Env. No: UPDAP 2019/17 Buluntu tipi: Yassı balta Malzemesi: Bazalt Yükseklik: $7.4 \mathrm{~cm}$ Genişlik: $5 \mathrm{~cm}$

8. Env. No: UPDAP 2019/18 Buluntu tipi: Yassı balta Malzemesi: Bazalt Yükseklik: $7.6 \mathrm{~cm}$ Genişlik: $5 \mathrm{~cm}$

9. Env. No: UPDAP 2019/2 Buluntu tipi: Yassı balta Malzemesi: Bazalt Yükseklik: $7.8 \mathrm{~cm}$ Genişlik: 3,6 cm 
10. Env. No: UPDAP 2019/3 Buluntu tipi: Keski Malzemesi: Serpantin Yükseklik: $3,8 \mathrm{~cm}$ Genişlik: $1,3 \mathrm{~cm}$

11. Env. No: BNZ.DZKŞL.125 Buluntu tipi: Havan eli Malzemesi: Andezit Yükseklik: 15,2 cm Genişlik: $8,3 \mathrm{~cm}$

12. Env. No: BNZ.DZKŞL.123 Buluntu tipi: Havan eli Malzemesi: Bazalt Yükseklik: $8,2 \mathrm{~cm}$ Genişlik: $5 \mathrm{~cm}$

13. Env. No: BNZ.DZKŞL.130 Buluntu tipi: Havan eli Malzemesi: Bazalt Yükseklik: 6,2 cm Genişlik: $3,5 \mathrm{~cm}$

14. Env. No: BNZ.DZKŞL.131 Buluntu tipi: Havan eli Malzemesi: Andezit Yükseklik: $6 \mathrm{~cm}$ Genişlik: $5,5 \mathrm{~cm}$

15. Env. No: BNZ.DZKŞL.126 Buluntu tipi: Havan eli Malzemesi: Andezit Yükseklik: 6 cm Genişlik: $5,5 \mathrm{~cm}$

16. Env. No: BNZ.DZKŞL.127 Buluntu tipi: Ezme taşı Malzemesi: Andezit Yükseklik: 10,5 cm Genişlik: $15 \mathrm{~cm}$

17. Env. No: BNZ.DZKŞL.129 Buluntu tipi: Ezme taşı Malzemesi: Andezit Yükseklik: 12,5 cm Genişlik: $13,2 \mathrm{~cm}$

18. Env. No: BNZ.DZKŞL.128 Buluntu tipi: Ezme taşı Malzemesi: Andezit Yükseklik: 10,3 cm Genişlik: $12 \mathrm{~cm}$

19. Env. No: BNZ.DZKŞL.134 Buluntu tipi: Çanak ağı parçası Malzemesi: Mermer Çapı: $17,5 \mathrm{~cm}$

20. Env. No: BNZ.DZKŞL.128 Buluntu tipi: Kap eklentisi Malzemesi: Mermer Yükseklik: $12,5 \mathrm{~cm}$ Genişlik: $7,5 \mathrm{~cm}$

21. Env. No: BNZ.DZKŞL.137 Buluntu tipi: Minyatür Kase parçası Malzemesi: Mermer Çapı: $7 \mathrm{~cm}$

22. Env. No: BNZ.DZKŞL.135 Buluntu tipi: Kap gövdesi Malzemesi: Mermer

23. Env. No: BNZ.DZKŞL.132 Buluntu tipi: Kap taslağı ? Malzemesi: Mermer

24. Env. No: BNZ.DZKŞL.133 Buluntu tipi: Kaide parçası Malzemesi: Mermer Çapı: $19 \mathrm{~cm}$ 


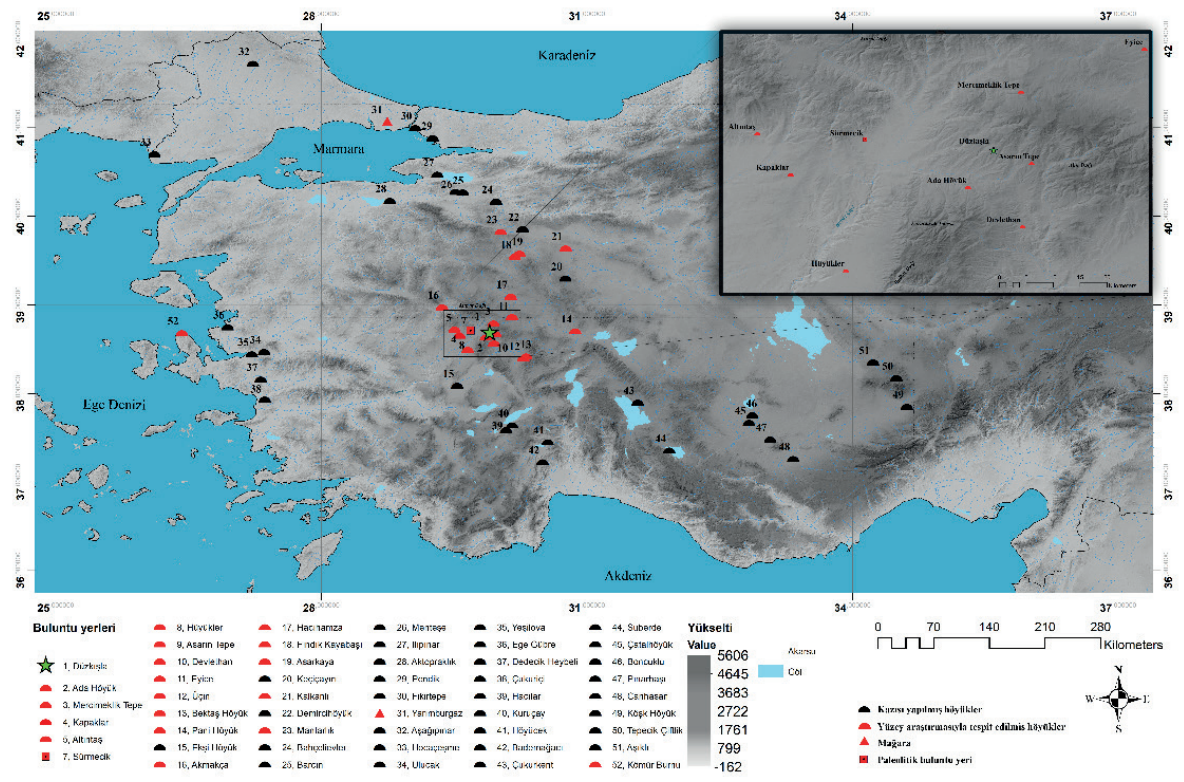

Harita 1. Makalede geçen buluntu yeri ve coğrafi isimleri içeren harita.

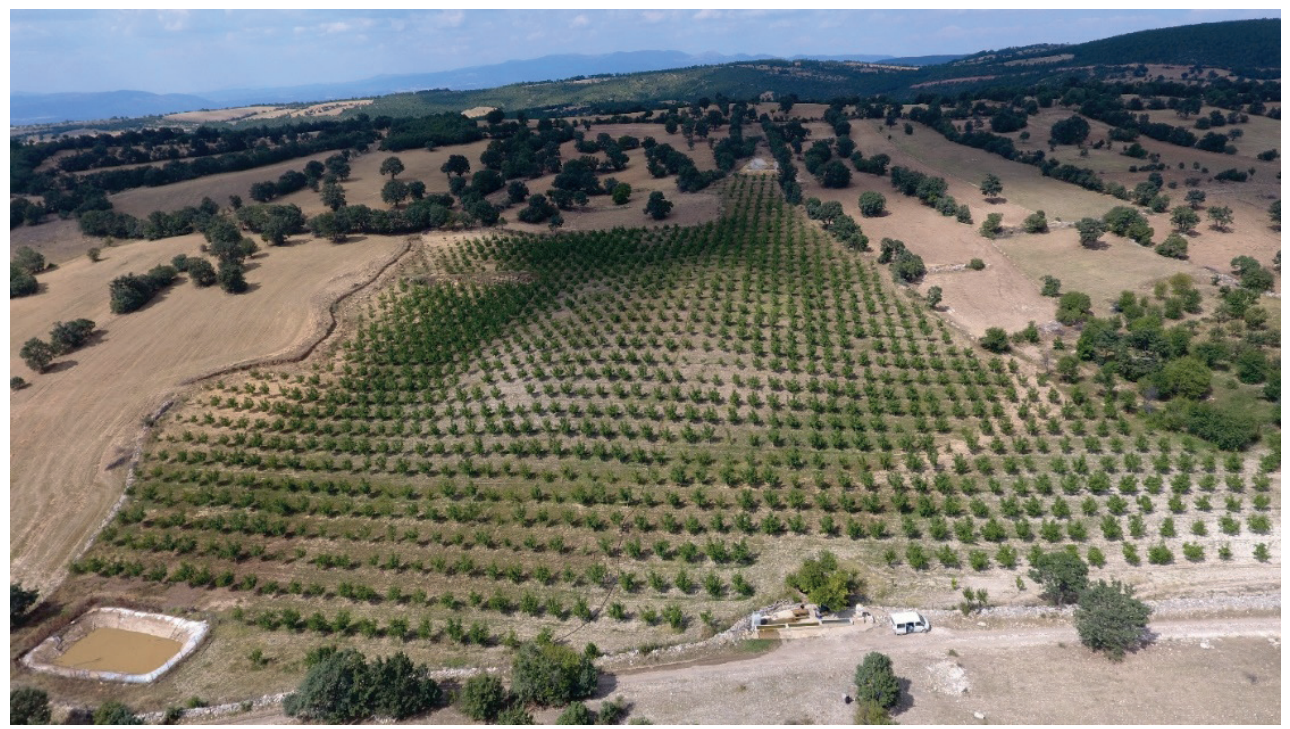

Resim 1. Düzkışla Höyük Hava Fotoğrafı (Güneyden). 

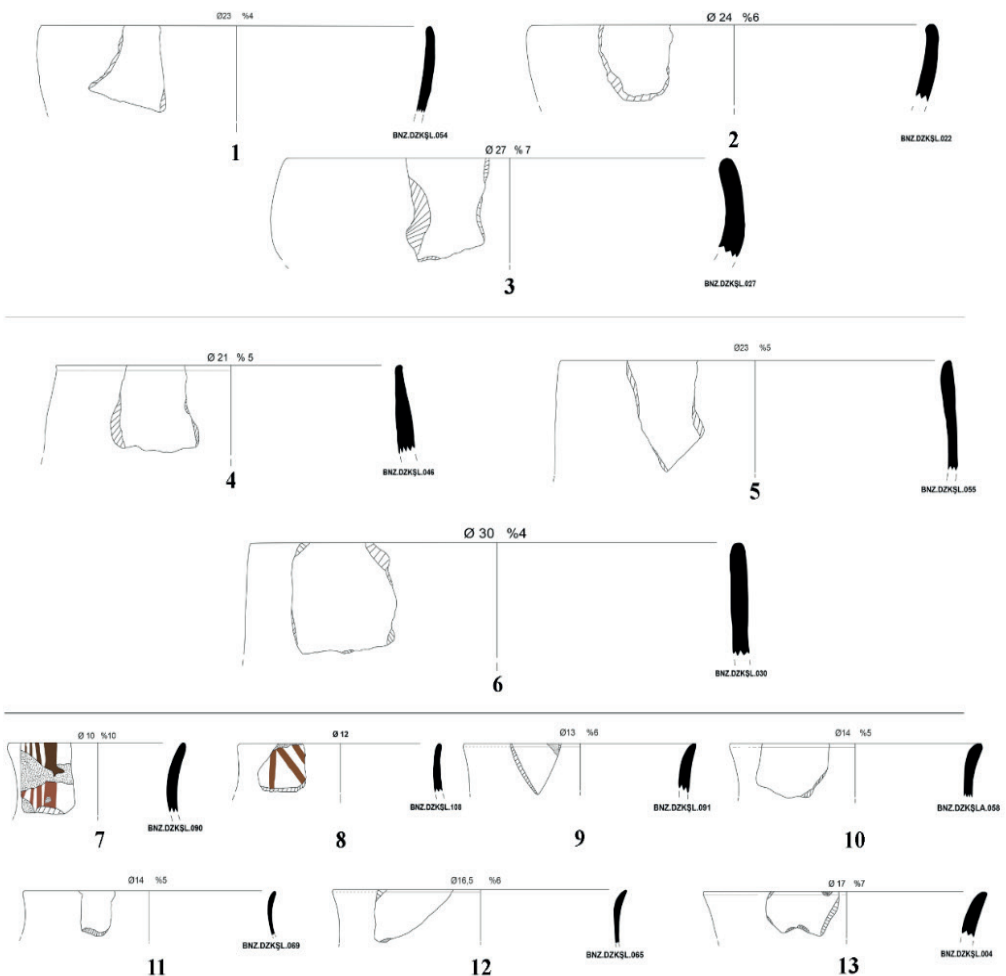

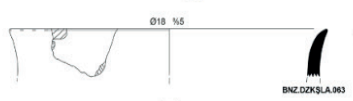

14
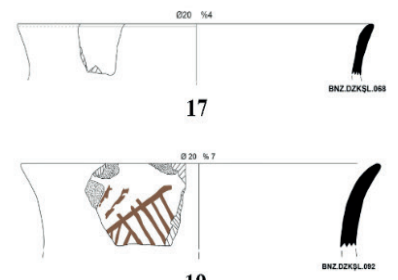

19

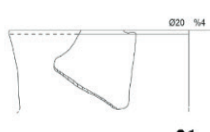

21

12

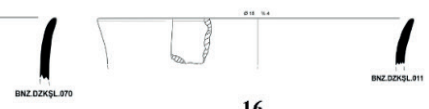

15

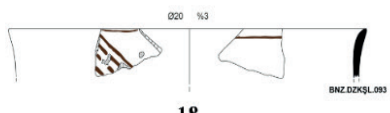

18

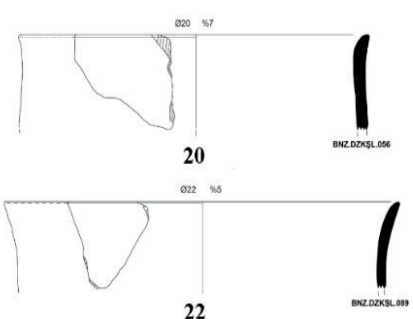

22

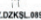

Resim 2. Geç Neolitik-Erken Kalkolitik Çağ Çanak Çömleği (PÇa1-PÇa2-PÇa3). 

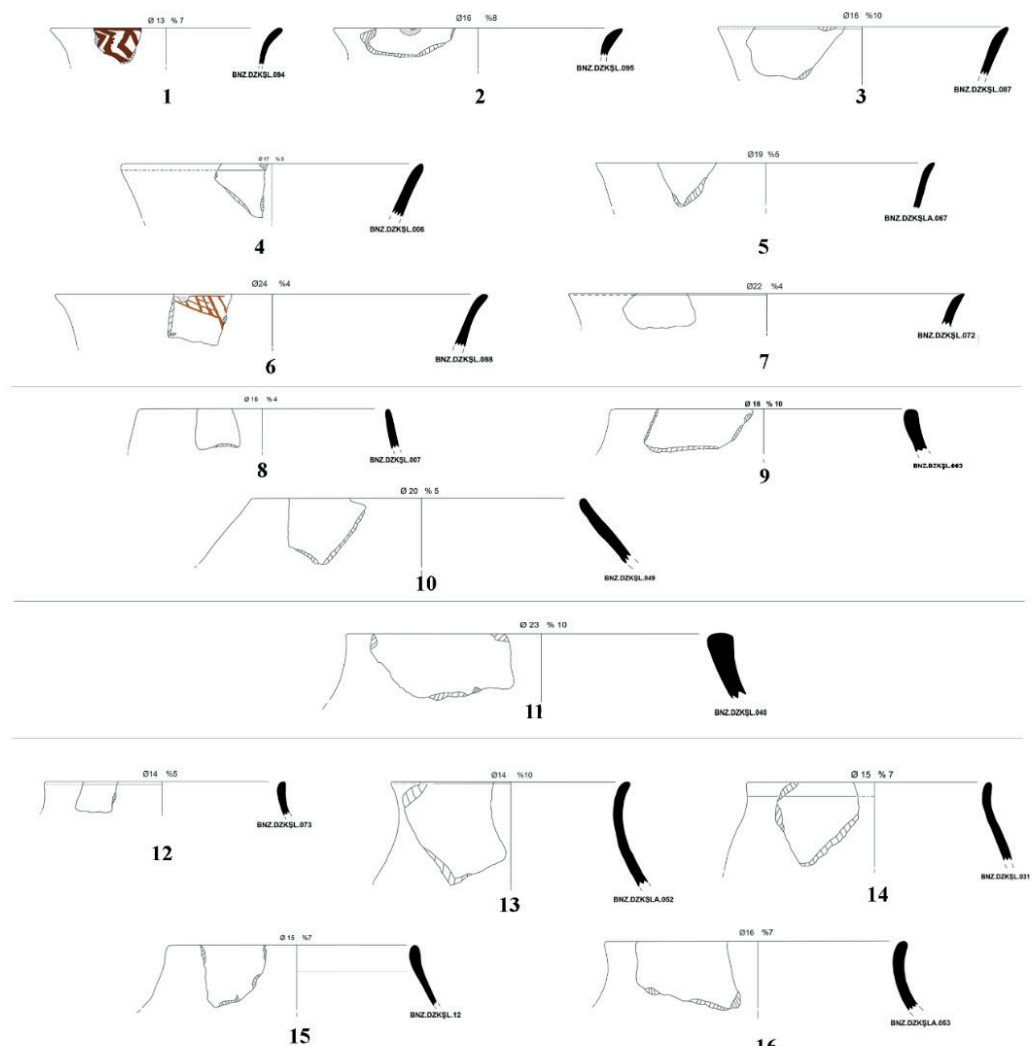

15
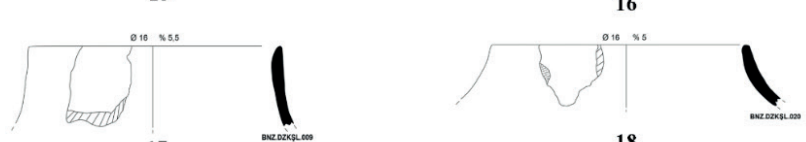

17

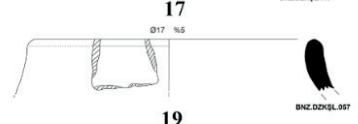

18
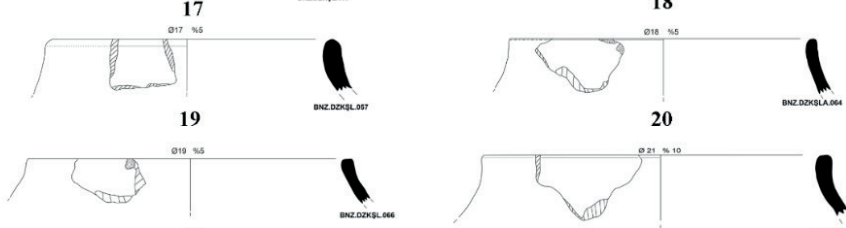

21

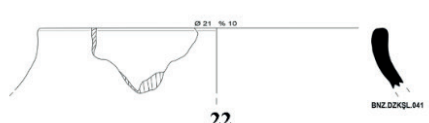

22

Resim 3. Geç Neolitik-Erken Kalkolitik Çağ Çanak Çömleği (PÇa4-PÇö1-PÇö2-PÇö3). 

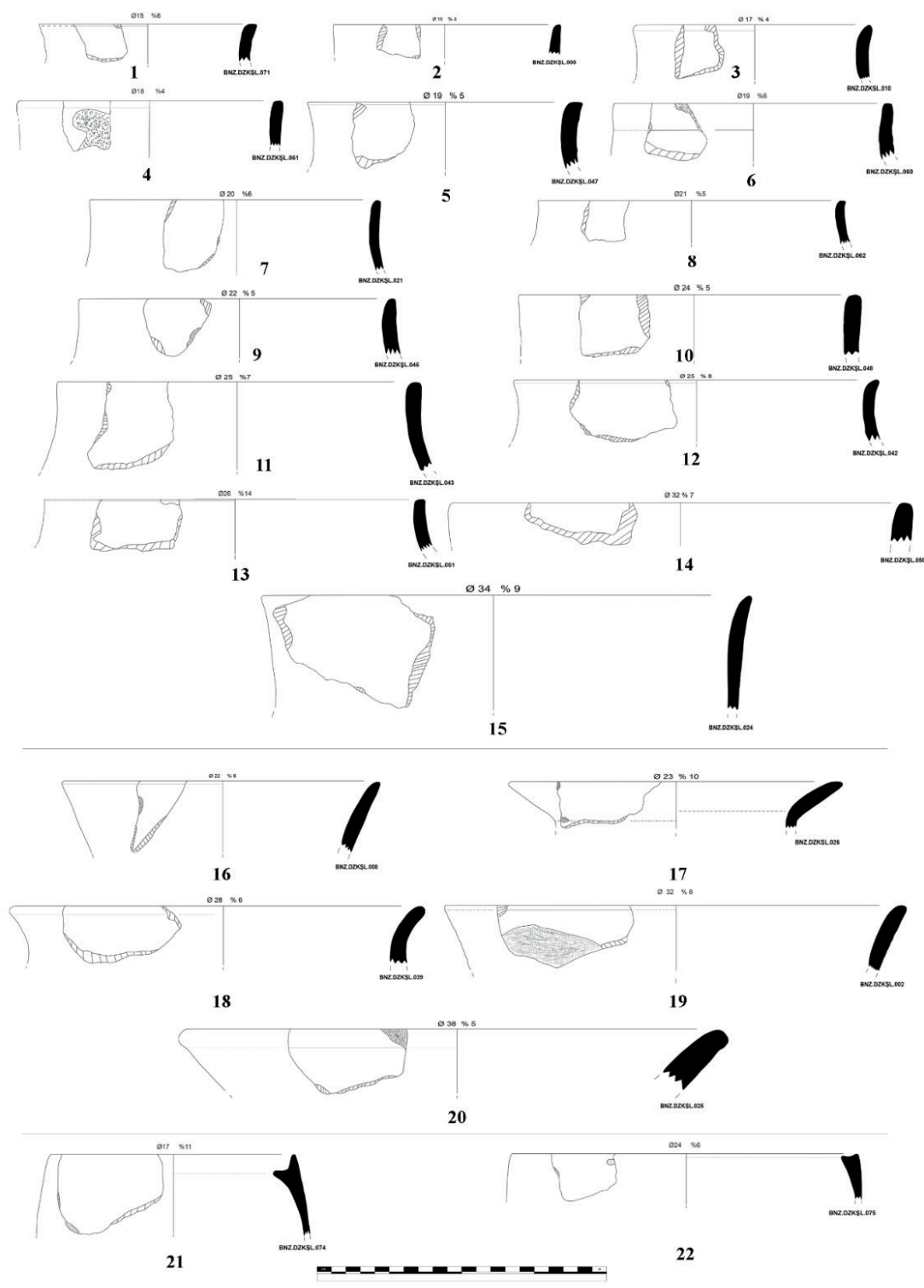

Resim 4. Geç Neolitik-Erken Kalkolitik Çağ Çanak Çömleği (PÇö4-PÇö5-PÇö6). 


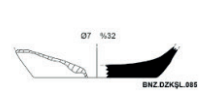

1

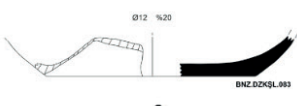

2

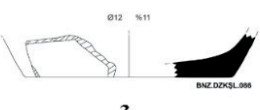

3

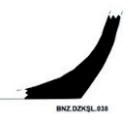

5

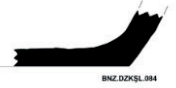

6

\section{(7), P}
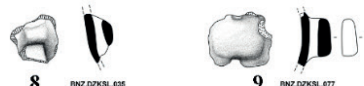

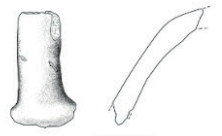

10

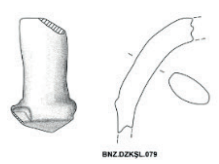

11

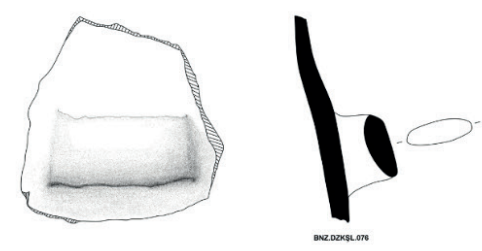

12

Resim 5. Geç Neolitik-Erken Kalkolitik Çağ Çanak Çömleği (PDip1-PT1-PT2-PKlp1-3). 

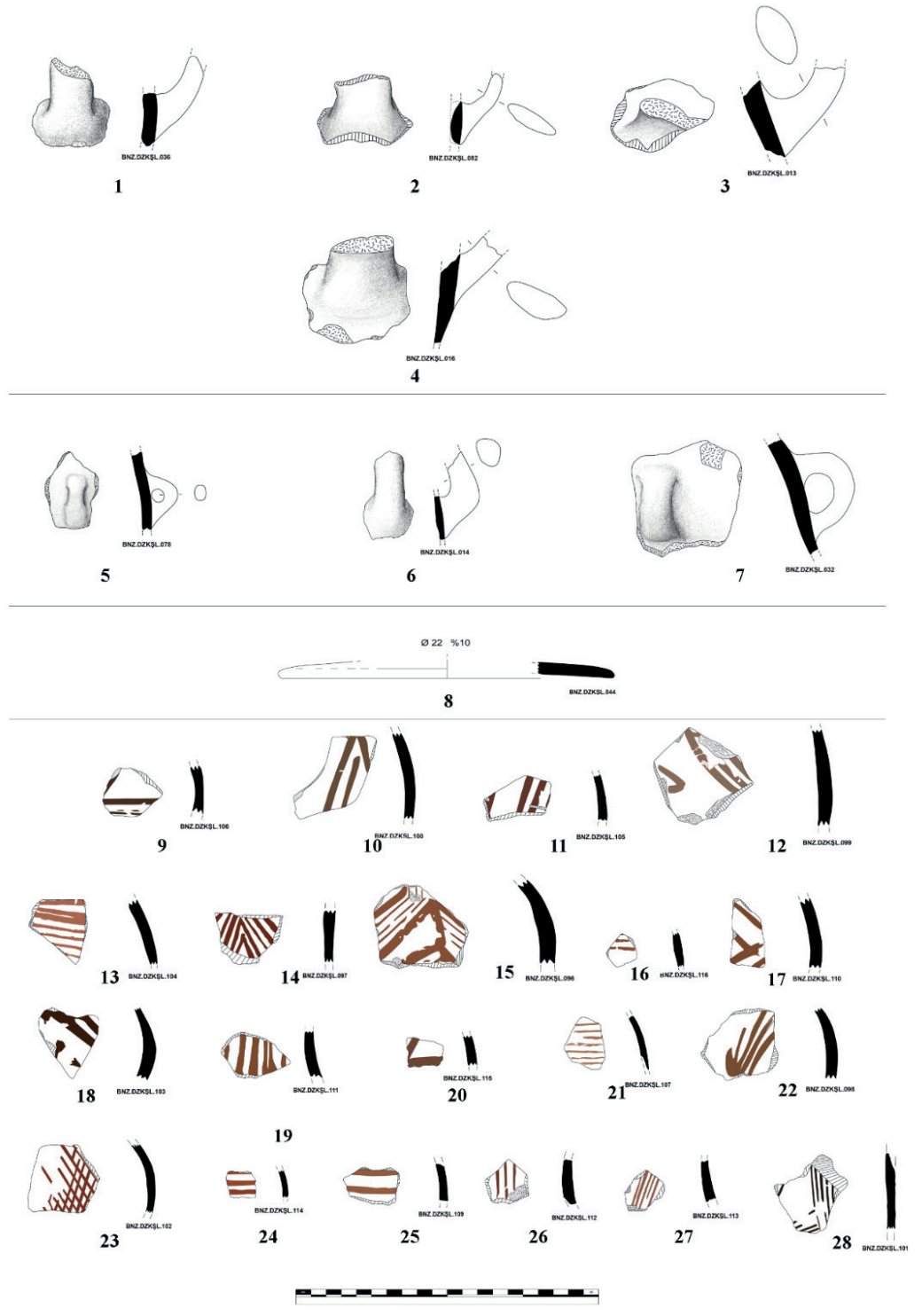

Resim 6. Geç Neolitik-Erken Kalkolitik Çağ Çanak Çömleği (PKlp4-5- Kapak-Boyalılar). 

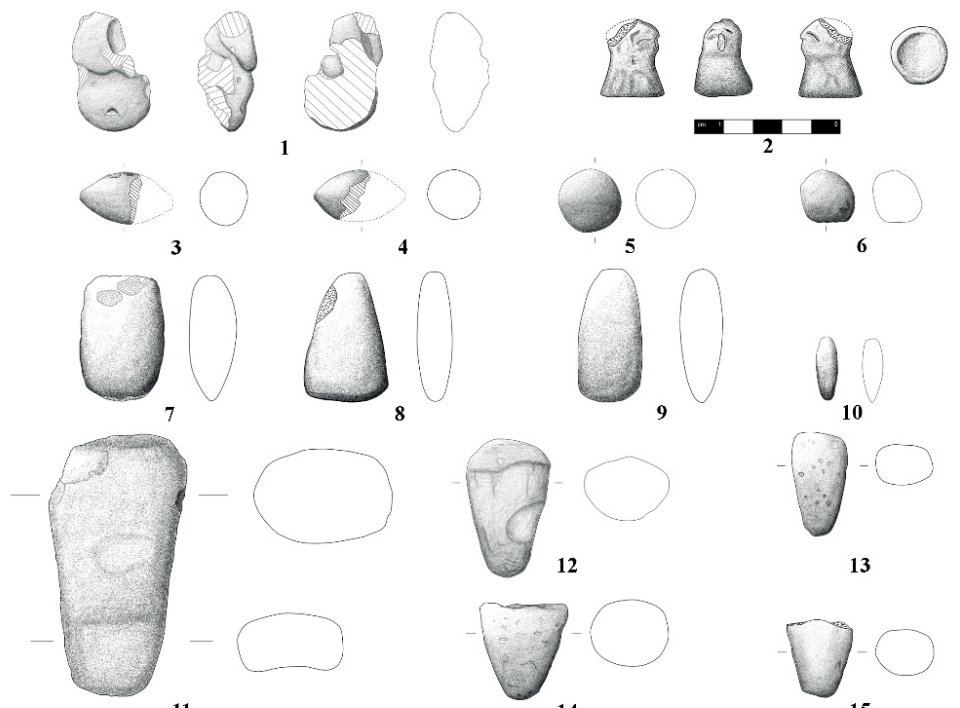

14

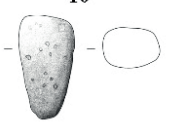

13

11

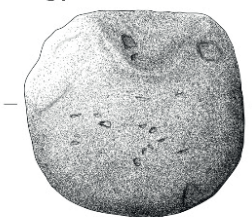

15
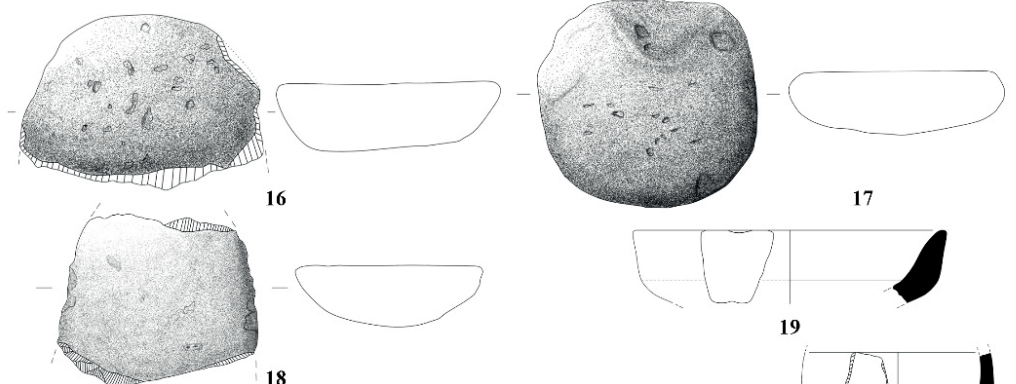

17
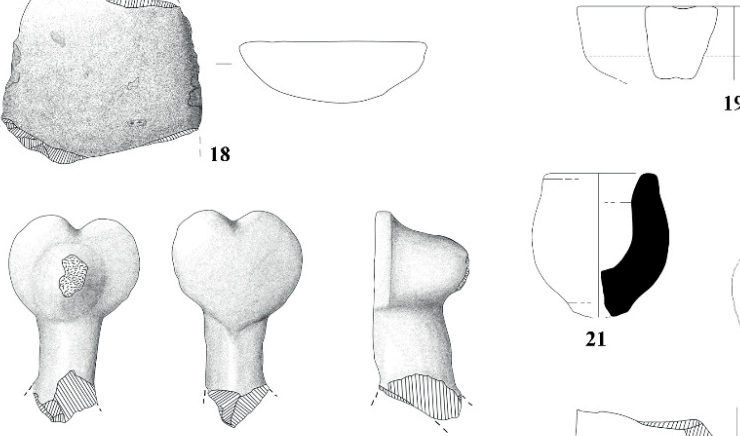

19
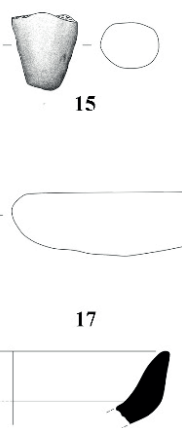

20
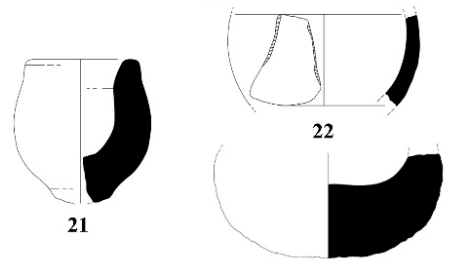

23

Resim 7. Geç Neolitik-Erken Kalkolitik Çağa ait diğer buluntular (Figürin-Sürtmetaş-Mermer). 